\title{
EVOLUTION OF THE SEMIDECIDUOUS-RIPARIAN FOREST (ECOTONE CERRADO-ATLANTIC FOREST) DURING THE LATE HOLOCENE, SOUTHEAST OF BRAZIL
}

\author{
MELINA MARA SOUZA (1) \\ Instituto de Educação, Ciência e Tecnologia do Sul de Minas, Avenida Dirce Pereira \\ Rosa, 300, 37701-100, Poços de Caldas, MG, Brazil. \\ melina.souza@ifsuldeminas.edu.br \\ FRESIA RICARDI-BRANCO (1) \\ Departamento de Geologia e Recursos Naturais, Instituto de Geociências, Universidade de Campinas, \\ Rua Carlos Gomes, 250, 13083-855, Campinas, SP, Brazil. \\ fresia@unicamp.br
}

\begin{abstract}
The floodplains of meandering rivers in southeastern Brazil represent places where the sedimentary record associated with the history of transition/ecotone areas and exchange of biomes accumulates, such as the Cerrado (Cerradão Forest) and Atlantic Forest (Semideciduous-Riparian Forest). The present study aims to use palynological, isotopic $\left(\delta^{13} \mathrm{C}, \delta^{15} \mathrm{~N}\right.$ and $\left.{ }^{14} \mathrm{C}\right)$, and anthracological indicators in cores taken from three abandoned meander bends to make inferences about environmental evolution, vegetation reconstruction, and climatic inferences. The study area is located in the Mogi Guaçu River Basin, in the countryside of São Paulo State. The studies show that $\sim 2,730$ BP (stage I), the area underwent through a more humid climatic phase compared to the current one, which allowed the expansion of the Riparian Semideciduous Forest. After that date, in stage II (1,800 to 510 BP), the percentage of the Cerrado (Cerradão Forest) increased, due to a drier period. From 510 BP to the present day (stage III), humidity has taken place with a new expansion of the Riparian Semideciduous Forest, although elements of Cerrado are present. Microscopic charcoal fragments were found in all stages and may infer the incidence of paleo-wildfires during the Late Holocene. The results indicate that both phytophysiognomies remained for the studied period, varying their expansion depending on the humidity present in each stage. Although lakes formed by abandoned meanders are not areas with the best palynological record, they are frequent environments in the interior of the continents. If properly interpreted, they may provide relevant information to vegetation and climatic changes for the areas.
\end{abstract}

Keywords: paleoenvironmental studies, Holocene, river dynamics, pollen grains, isotopic analysis, charcoal fragments.

RESUMO - As planícies de inundação de rios meandrantes no sudeste do Brasil representam locais nos quais se acumula o registro sedimentar associado à história de áreas de transição/ecótono e intercâmbio de biomas como o Cerrado (Floresta de Cerradão) e Mata Atlântica (Floresta Semidecídua-Ripariana). O presente estudo teve como objetivo utilizar indicadores palinológicos, isotópicos $\left(\delta^{13} \mathrm{C}, \delta^{15} \mathrm{~N}\right.$ e $\left.{ }^{14} \mathrm{C}\right)$ e antracológicos em testemunhos retirados de três meandros abandonados para realizar inferências sobre evolução ambiental, reconstrução da vegetação e inferências climáticas na Bacia do Rio Mogi Guaçu, no interior do Estado de São Paulo. Os estudos apontaram que há 2.730 AP (estágio I), a área passou por uma fase climática mais úmida que a atual, que possibilitou a expansão da Floresta Semidecídua-Ripariana. Após essa data no estágio II (1.800 a 510 AP), a porcentagem de táxons do Cerrado (Cerradão) aumentou, em decorrência de um estágio mais seco. A partir de 510 AP até os dias atuais (estágio III), a umidade retornou com uma nova expansão da Floresta Semidecídua-Ripariana, embora também estejam presentes ainda elementos do Cerrado. Fragmentos de carvão microscópicos foram encontrados em todos os estágios, podendo então inferir a incidência de paleoincêndios durante o Neo-holoceno. Os resultados indicam que as fitofisionomias permaneceram pelo período estudado, variando sua expansão dependendo da umidade presente em cada estágio. Embora lagos formados por meandros abandonados não sejam os locais com o melhor registro palinológico, eles são ambientes muito frequentes no interior dos continentes e que se devidamente interpretados podem aportar informações importantes vegetacionais e possivelmente climáticas para estas áreas.

Palavras-chave: estudos paleoambientais, dinâmica fluvial, grãos de pólen, análises isotópicas, fragmentos de carvão. 


\section{INTRODUCTION}

Studies related to vegetation and evolution in flooded areas (e.g. abandoned meander bends) during the Holocene are scarce in Brazil. Rivers represent the most frequent, significant, and dynamic agents in transport and deposition of sediments in areas covered by the transition from the Cerrado to the Seasonal Semidecidual Forest (Durigan, 1994; Durigan et al., 2003; Graham, 2011; Oliveira-Filho et al., 2013). However, one of the main obstacles to study flooded areas is its sedimentary record, due to temporal and spatial variations in river channels, and occurrences of high energy events that may affect stability on riverbanks. Yet, it plays an essential role to comprehend the evolution of wetlands, as well as the balance of aquatic ecosystems to protect the riparian vegetation, and to maintain the biodiversity (Durigan, 1994; Durigan et al., 2003; Graham, 2011; Oliveira-Filho et al., 2013). In São Paulo State, the Cerrado Biome has its most southern occurrences. The studied area is one of the ecotone zones between Cerradão Forest (the Cerrado Biome, phytofisiognomy) and Semideciduous Forest (the Atlantic Forest Biome, phytophysiognomy). The Riparian Forest that occurs on the banks of the Mogi Guaçu River in the Ecological Station presents clear influence of the Semideciduous Seasonal Forest (Gibbs \& Leitão Filho, 1978; Gibbs et al., 1983; Mantovani et al., 1985; Mantovani \& Martins, 1988; 1993; Durigan et al., 2003; Gomes et al., 2004; Siqueira \& Durigan, 2007). Moreover, the natural vegetation located in the inner part of the Mogi Guaçu Ecological Station (MGES) (approximately $2 \mathrm{~km}$ from the river) represents the type of forest that may be associated with the Cerradão Forest (Gibbs et al., 1983; Mantovani et al., 1985; Mantovani \& Martins, 1988; 1993). The Riparian Forest is affiliated with the Semideciduous Forest (SemideciduousRiparian Forest), since the river influence provides stable conditions (high humidity, hydromorphic soils), and it is less rigorous when compared to the Cerrado. Its floristic composition comprises species that are typical of flooded areas, and others not adapted to flood periods (Mantovani et al., 1989; Durigan et al., 2003). The SemideciduousRiparian Forest follows the drainage, consisting of a low and open canopy with dense scrubs. In addition, it is under the river influence (endorheic zone) through a hydric cycle, and temporary floods (Gibbs \& Leitão-Filho, 1978; Aquino et al., 2013; Ricardi-Branco et al., 2015). The Cerrado is adapted to different conditions of seasonal climate, soils, relief, and anthropic influence that determine the similarity with the forest cover foliage formed by sclerophyllous trees and herbaceous/exfoliating stratum (Cassino et al., 2015). According to Batista \& Couto (1990), chemical and physical factors of the soil are determinant to the Cerrado (Cerradão Forest) present in MGES. The sedimentary record associated with the Riparian Forests is the evidence of floristic changes influenced by climate change, and it allows the study of paleoenvironmental variations through the proxy data used in the present research. Our main goal was to study the environmental reconstruction of the mid-course of the Mogi Guaçu River in the State of São Paulo during the Late Holocene. Thus, the use of paleoenvironmental indicators, such as palynological, isotopic, and anthracological analysis (charcoals), were essential to make paleoenvironmental inferences for the study area.

Finally, in order to achieve the proposed objectives, three cores recovered from the river plain in MGES were analyzed to mitigate possible gaps in the paleoenvironmental records, as a result of the dynamics associated with the meander bends of the Mogi Guaçu river.

\section{STUDY AREA}

\section{The Mogi Guaçu River and the study area}

The Mogi Guaçu River basin comprises a total area of $17,460 \mathrm{~km}^{2}$, with $14,653 \mathrm{~km}^{2}$ located in the northeastern portion of São Paulo State. It presents a rectangular shape and extends from the southwest to the northwest (Celarino et al., 2013). The Mogi Guaçu River presents a meandering course on its middle portion, which is the result of neotectonic actions that have raised its course. The spring of Mogi Guaçu River rises at Morro do Curvado, in the Bom Repouso Municipality, in Minas Gerais State (MG), at approximately $1,510 \mathrm{~m}$ altitude, and coordinates $22^{\circ} 30^{\prime} \mathrm{S} / 46^{\circ} 08^{\prime} \mathrm{W}$, in the Serra da Mantiqueira region, southeast of Brazil. After, it flows along approximately $530 \mathrm{~km}$. It flows into the Pardo River, a tributary of the Paraná River, $483 \mathrm{~m}$ above sea level, between the coordinates $20^{\circ} 53^{\prime} 24^{\prime \prime} \mathrm{S}$ and $48^{\circ} 10^{\prime} 36^{\prime \prime} \mathrm{W}$, in the NE of São Paulo State (Zancopé et al., 2009). Within the territory of São Paulo State, Mogi Guaçu River flows through the Peripheral Paulista Depression, predominantly over fine sandstone, mudstones, and shales of the Paraná Basin (Itararé Group and Aquidauana Formation) until its mouth in Pardo River (Zancopé et al., 2009). It is observed a superficial coverage from the Cenozoic (alluvial deposits and colluvium-alluvial deposits) located along its banks (Perrotta et al., 2005). Some lithostratigraphic units found near the river present medium or high susceptibility to soil erosion, due to the unconsolidated sediments, or the combination of lithology and the local relief (Zancopé et al., 2009). The study area is located in the mid-portion of Mogi Guaçu River, in the MGES of the Forestry Institute of Campininha Farm (Figure 1). Campininha Farm is located in the Municipality of Mogi Guaçu, between the geographic coordinates $22^{\circ} 0$ ' and $22^{\circ} 18^{\prime} \mathrm{S}$, and $47^{\circ} 08^{\prime}$ and $47^{\circ} 11^{\prime} \mathrm{W}$, in São Paulo State. The mean annual temperatures range from $20.5^{\circ} \mathrm{C}$ to $22.5^{\circ} \mathrm{C}$, and the mean annual precipitation ranges from $1,400 \mathrm{~mm}$ to $1,600 \mathrm{~mm}$. During the rainy season (October to March), the mean precipitation accumulated ranges from $1,100 \mathrm{~mm}$ to $1,250 \mathrm{~mm}$, and in the dry season (April to September) from $250 \mathrm{~mm}$ to $300 \mathrm{~mm}$ (CBH-Mogi, 1999), characterizing South American Monsoon System (SAMS). The Mogi Guaçu River flood events occur in the rain season (October to March), and in pulses of short time when the river discharge is high, $380 \mathrm{~m}^{3} \mathrm{~s}^{-1}$ (Lobo et al., 2001). 
A

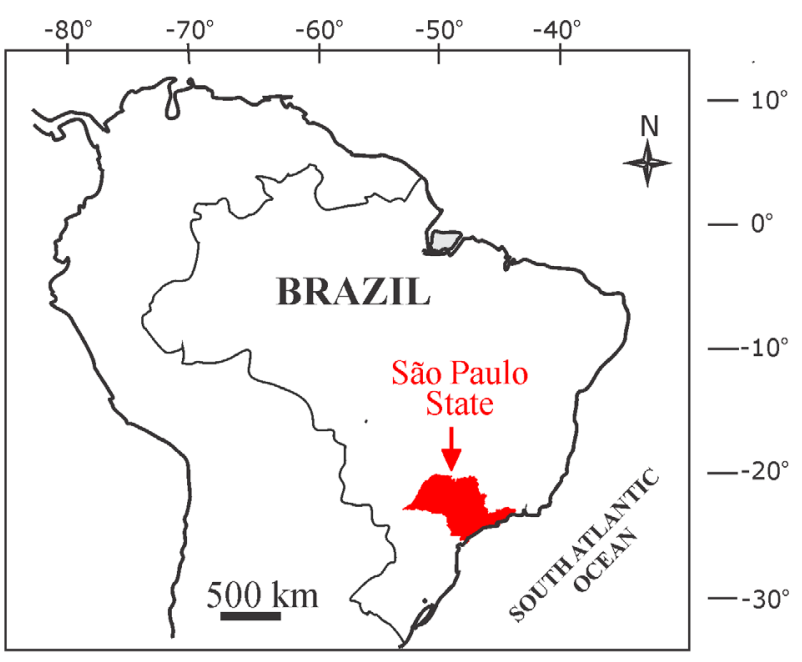

B

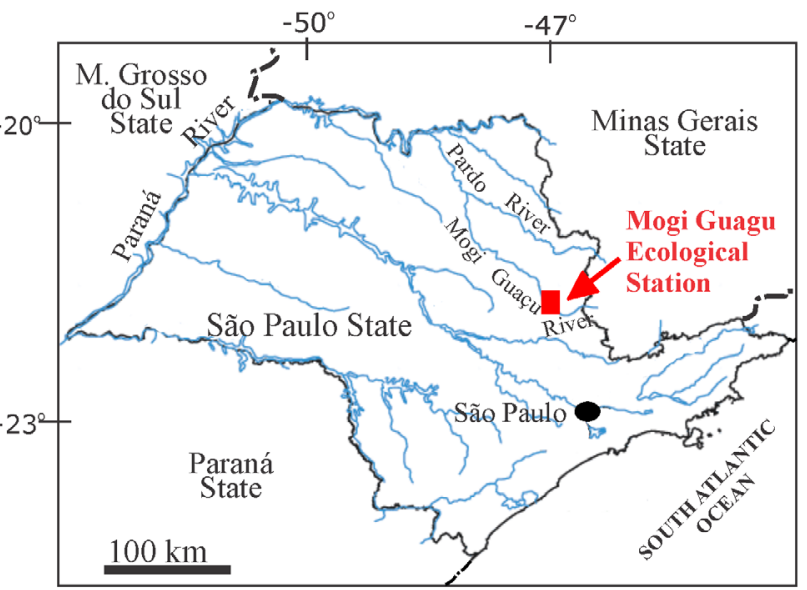

\section{C}

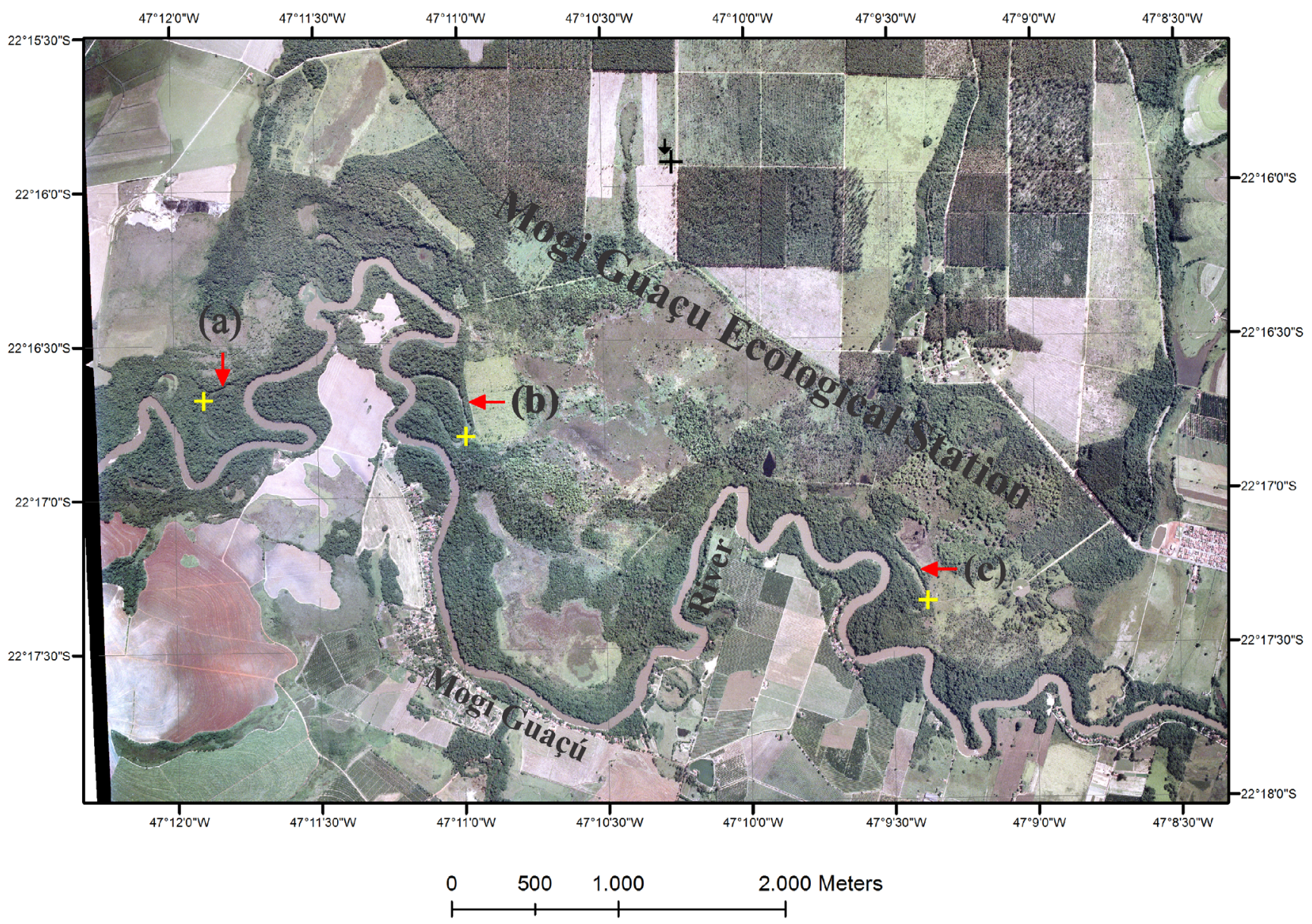

Figure 1. Location maps of São Paulo State in Brazil (A), Mogi Guaçu River course and Mogi Guaçu Ecological Station (MGES) in São Paulo State (B), and Aerial Photography (2012) showing the studied locations at MGES (C), and the points where the cores were drilled, and each one pointed by a yellow cross: a, Fundão Lake; b, Pedra Lake, and c, Catingueiro Lake.

\section{The Ecotone characterization at MGES}

The term Riparian Forest is the most suitable to represent the plant associations that occur along watercourses (Ribeiro \& Walter, 2008). It comprises the vegetation close to watercourses, and the vegetation shows influences of the
Semideciduous Seasonal and Cerradão forests. According to vegetation surveys carried out for the study area within forest of phytophysiognomies (Gibbs \& Leitão Filho, 1978; Gibbs et al., 1983; Mantovani et al., 1985; Mantovani \& Martins, 1988; 1993; Durigan et al., 2003), two groups present their 
current distribution influenced by the river system and soils: (i) the phytophysiognomy associated with watercourses (Semideciduous-Riparian Forest), and the phytophysiognomy not associated with watercourses (Cerradão Forest). Wetlands (vegetation with river influence) within the MGES are located in the transition area of forest and the edge of watercourses (Eiten, 1963). The Semideciduous-Riparian Forest is characterized by Fabaceae (e.g. Anadenanthera sp.), Euphorbiaceae, Lauraceae, Tiliaceae (e.g. Apeiba tibourbou Aubl.), Apocynaceae (e.g. Aspidosperma sp.), Sapindaceae, Anacardiaceae, Cannabaceae [(e.g. Trema micranta (L.) Blume)], Bignoniaceae (e.g. Tabebuia sp.), and Arecaceae families. It presents species of Boraginaceae, Myrtaceae, and Rubiaceae families (Gibbs \& Leitão Filho, 1978; Gibbs et al., 1983; Mantovani et al., 1985; Mantovani \& Martins, 1988; 1993; Durigan et al., 2003). The Cerradão Forest is characterized by arboreal and herbaceous components. The arboreal component is less diverse and characterized by genera of Fabaceae, Euphorbiaceae, Myrtaceae, and Rubiaceae. The herbaceous and most diverse component in species is characterized by Asteraceae, Poaceae, and Fabaceae (Mantovani \& Martins, 1993; Ribeiro \& Walter, 2008; Oliveira-Filho et al., 2013). The contact area of Semideciduous-Riparian and Cerradão forests present species of Araliaceae, Malpighiaceae and Amaranthaceae, and genera in common of Diclinanona sp., characterizing the ecotone.

\section{MATERIAL AND METHODS}

Three cores were drilled in three lakes generated from abandoned meander bends located on the banks of Mogi Guaçu River: Catingueiro Lake, Pedra Lake, and Fundão Lake. The drillings were carried out to reduce possible gaps in sedimentary records, due to river dynamics associated with the meanders of Mogi Guaçu River.

\section{Features of lakes and core drilling}

The three studied lakes flood during the rainy months. They present semicircular shape, and maximum depth of $5 \mathrm{~m}$, in the rain season. Fundão Lake $\left(22^{\circ} 16^{\prime} 39.80^{\prime \prime} \mathrm{S} / 47^{\circ} 11^{\prime} 48.5^{\prime \prime} \mathrm{W}\right)$ is approximately $40 \mathrm{~m}$ wide and $680 \mathrm{~m}$ long, and it is located about $220 \mathrm{~m}$ from the river channel. Pedra Lake $\left(22^{\circ} 16^{\prime} 46.32^{\prime \prime} \mathrm{S} / 47^{\circ} 11^{\prime} 02.5^{\prime \prime} \mathrm{W}\right)$ is $70 \mathrm{~m}$ wide and $800 \mathrm{~m}$ long, and it is about $246 \mathrm{~m}$ from Mogi Guaçu River. Catingueiro Lake ( $\left.22^{\circ} 17^{\prime} 18.50^{\prime \prime} \mathrm{S} / 47^{\circ} 9^{\prime} 25.01^{\prime \prime} \mathrm{W}\right)$ is $22 \mathrm{~m}$ wide and 900 $\mathrm{m}$ long, and it is $230 \mathrm{~m}$ from Mogi Guaçu River. Sampling was performed by fixing tubular drillers, and inside each one a 5-cm diameter transparent disposable liner. According to Byrnes (1994), the tubular sampler allows collecting little altered samples by hand, while retaining its original physical and chemical characteristics. The three cores reached the maximum depth of $179 \mathrm{~cm}$ in Fundão Lake, $131 \mathrm{~cm}$ in Pedra Lake, and $156 \mathrm{~cm}$ in Catingueiro Lake. The cores were not deeper due to thick layers of sand associated with paleochannels (thicker than $50 \mathrm{~cm}$ ), a quite common feature in abandoned meander bends. The cores were opened, measured, and described in the Laboratory of Paleo-Hydrogeology of the Institute of Geosciences, University of Campinas (IGUNICAMP). For each core, samples were retrieved every $2 \mathrm{~cm}$. Thirty-three samples were obtained for Fundão Lake, starting in the interval 4-6 up to $164-166 \mathrm{~cm}$. Twentyfour samples were obtained for Pedra Lake, starting in the interval 4-6 to $120-122 \mathrm{~cm}$, and 25 samples were obtained for Catingueiro Lake, starting in the interval 0 to 126-129 $\mathrm{cm}$. The samples were allocated in appropriate plastic bags, numbered, and stocked in refrigerator.

\section{Modern pollen rain study}

To obtain data on the environment and local flora of each studied site (Fundão, Pedra and Catingueiro lakes), surface sediment samples were collected from water/sediment interface randomly, and from the soil of each core at its surrounding area. In addition, sediment was collected from inside the bromeliad tanks, as they are natural pollen grain collectors (Amaral et al., 2006). A total of 12 samples (four from each lake) were collected with a 10-gr-plastic tube. At the laboratory, they were processed according to the same chemical treatment used for the palynological samples (Faegri \& Iversen, 1989). The samples belonging to Fundão Lake were identified as LFCp1, LFCp2 for sediments, and LFCp3 and LFCp4 for bromeliads. The samples from Pedra Lake were identified as LPCp1, LPCp2 and LPCp3 for sediments, and LPCp4 for bromeliads. The samples from Catingueiro Lake were identified as LCCp1, LCCp2 for sediments, and LCCp3 and LCCp4 for bromeliads. After the chemical process, two samples were sterile for palynology, one from Pedra Lake (LPCp3) and one from Catingueiro Lake (LCCp2).

\section{Palynological studies from cores and chemical treatment of palynology samples}

The samples were recovered every $2 \mathrm{~cm}(10$ grams per sample) in the three cores. The chemical treatment used in the palynological samples followed the classical methodology of Faegri \& Iversen (1989) for Quaternary sediments, which includes the dissolution and removal of silicates and humic acids to obtain palynomorphs. A few drops of glycerin were added to residue, and the final volume was quantified by using micropipettes. Non-permanent microscopy slides were prepared using the residue amount of 50 microliters for the study and micro-photographical record. It was used a Zeiss Axio Imager.A1 optical microscope with 100x-lens. In Fundão Lake core, four out of 18 samples analyzed were considered fertile and used in palynological interpretation. In Pedra Lake core, 24 samples were processed, and 13 presented pollen. In Catingueiro Lake core, 17 samples were analyzed, and two were fertile and used in palynological interpretation. Then, a diagram with the individual percentages of each taxon, and the ecological grouping was defined using the method of Court (1974) to calculate the concentrations and percentages. The slides were horizontally read, with no spacing between columns, and up to 300 pollen grains were counted (when possible) for each level. Data were expressed as a percentage of each taxon in relation to the partial sum. That includes the arboreal (AP), non-arboreal/herbaceous 
(NAP), and undetermined pollen grains. Aquatics, and spores were counted separately. The identification was carried out by family level and, when possible, genus. For each locality, pollen grains of aquatic plants and spores were excluded from the total sum in the diagrams. The diagrams with pollen percentage and concentration of each lake were prepared with Psimpoll ${ }^{\circledR} 4.27$ and Corel Draw ${ }^{\circledR}$ X4 4 softwares. Psimpoll draws and analyzes paleoecological and stratigraphic data to summarize the palynological results of each core studied. Based on this premise, one diagram was built for each lake and for the modern pollen rain. As it is an ecotone, diagrams of formations within the vegetation were not performed, since a large quantity of pollen grains could only be determined at family level, and the difference between composition of the studied forests occurs at the level of species and presenting genera in common (Gomes et al., 2004; Oliveira-Filho et al., 2013). Our samples do not present enough resolution to separate the studied sets in a reliable way. A catalog was set up to facilitate identification, describing the types of pollen grains and spores found on slides at each level. From the catalogs, the palynomorphs (pollen grains and spores) were described and separated by family and genus (when possible). A bibliographical research was performed for each type identified, regarding its main occurrences and environmental characteristics. The classification of palynomorphs was based on specific literature of pollen grain atlas of SalgadoLabouriau (1973); Markgraf \& D'Antoni (1978); Carreira et al. (1996); Colinvaux et al. (1999); Carreira \& Barth (2003); Silva et al. (2010). We also used the DGRN/IG/UNICAMP pollen atlas, which has 650 types of pollen grains from several biomes of Brazil and Venezuela.

\section{Isotopic analysis}

The isotopic composition $\left({ }^{15} \mathrm{~N},{ }^{12} \mathrm{C}\right.$ and $\left.{ }^{13} \mathrm{C}\right)$ was analyzed every $10 \mathrm{~cm}$ depth, obtaining 18 samples from Fundão Lake, 15 from Pedra Lake, and 16 from Catingueiro Lake. Some samples were studied twice, as they did not present enough gas and were considered sterile. Samples were analyzed in the ${ }^{14} \mathrm{C}$ Laboratory and the Laboratory of Stable Isotopes, CENA/ USP/Piracicaba. The Mass Spectrometry (MS) or Isotope Ratio Mass Spectrometer (IRMS) was used to discriminate the photosynthetic system of $\mathrm{C}_{3}$ and $\mathrm{C}_{4}$ plants. The instrument separates positive and negative ions produced from atoms or molecules, from the simplest to the most complex, according to the mass/charge ratio (Pessenda et al., 2005). Measured ${ }^{13} \mathrm{C} /{ }^{12} \mathrm{C}$ ratios $\left(\delta^{13} \mathrm{C}\right)$ were calculated relative to the PDB-1 standard.

\section{Chronology}

For the chronology of the events, 19 bulk organic sediment samples (11 from Fundão Lake, four from Pedra Lake, and four from Catingueiro Lake) were collected and sent to Beta Laboratory, Miami, USA, for dating by AMS ${ }^{14} \mathrm{C}$. Results were calibrated using the SHCal 13 curve (Hogg et al., 2013), with the software OxCal (Bronk Ramsey, 2001), suitable for South American samples.

\section{Charcoals}

The analysis of charcoal fragments was performed for the same palynological intervals studied, and for those that were not out of chronological order, to obtain a clear profile representation. It was used an amount of $2 \mathrm{~cm}^{3}$ per sediment sample for each depth (Whitlock \& Larsen, 2001). The samples were dried at $60^{\circ} \mathrm{C}$ for four hours, and then, sieved to facilitate sorting. The next step was to select the material in a stereomicroscope (Zeiss-KL 1500 LCD) for counting and measuring the fragments to obtain the size and variation of fragments in each level. Finally, it was reported the presence or absence of charcoals during the reading of different levels in palynological non-permanent microscopy slides.

\section{RESULTS}

\section{Modern pollen rain}

Twenty-four pollen types were identified in the pollen rain, in a total of 1,628 pollen grains. We found 1,046 arboreal pollen grains (AP), 424 non-arboreal pollen grains (NAP), and 158 undetermined. Aquatic taxa were represented by 138 spores and 318 types. The predominant pollen grains in Semideciduous-Riparian Forest belong to Apocynaceae, Arecaceae, and Melastomataceae. The Cerradão Forest is represented by Euphorbiaceae (Sebastiania sp. and Euphorbia sp.), and Mimosaceae, Araliaceae, Asteraceae, Myrtaceae, Malpighiaceae, Poaceae, Rubiaceae, Malvaceae, Lamiaceae and Sapotaceae, which correspond to the ecotone. The pollen of Pinus sp. belongs to a species introduced in the mid twentieth century (Figure 2). In Fundão Lake (Figure 2), the arboreal pollen grains contribute with $41 \%$ of the total sum, the non-arboreal pollen grains accounted for $23 \%$, aquatic plants $10 \%$, spores $17 \%$, and $9 \%$ remained undetermined. The predominant families were Euphorbiaceae, Araliaceae, Mimosaceae, Melastomataceae, and Malpighiaceae, and among the gymnosperms, Pinaceae (Pinus sp.). In Pedra Lake (Figure 2), the arboreal pollen grains contribute with $20 \%$ of the total sum. The nonarboreal pollen grains represent $36 \%$, aquatic plants $24 \%$, spores $9 \%$, and $11 \%$ remained undetermined. Among arboreal taxa prevail Araliaceae, Euphorbiaceae, Arecaceae, Myrtaceae and Mimosaceae. In relation to gymnosperms, the predominant genus is Pinus sp., and among herbaceous taxa the Poaceae, and Asteraceae families prevail (Figure 2). In Catingueiro Lake, the arboreal grains contribute with $71 \%$ of the total sum, the non-arboreal $8 \%$, aquatic plants $11 \%$, spores $2 \%$, and $8 \%$ remained undetermined. The most representative arboreal pollen grains belong to Euphorbiaceae, Apocynaceae, Mimosaceae, Araliaceae, Myrtaceae and Arecaceae. Among herbaceous taxa the Asteraceae and Poaceae families prevail (Figure 2). The spores belong mainly to Thelypteridaceae family. We provide a list (Appendix 1) comparing the types found in modern pollen rain, and cores at Fundão, Pedra, and Catingueiro lakes. 


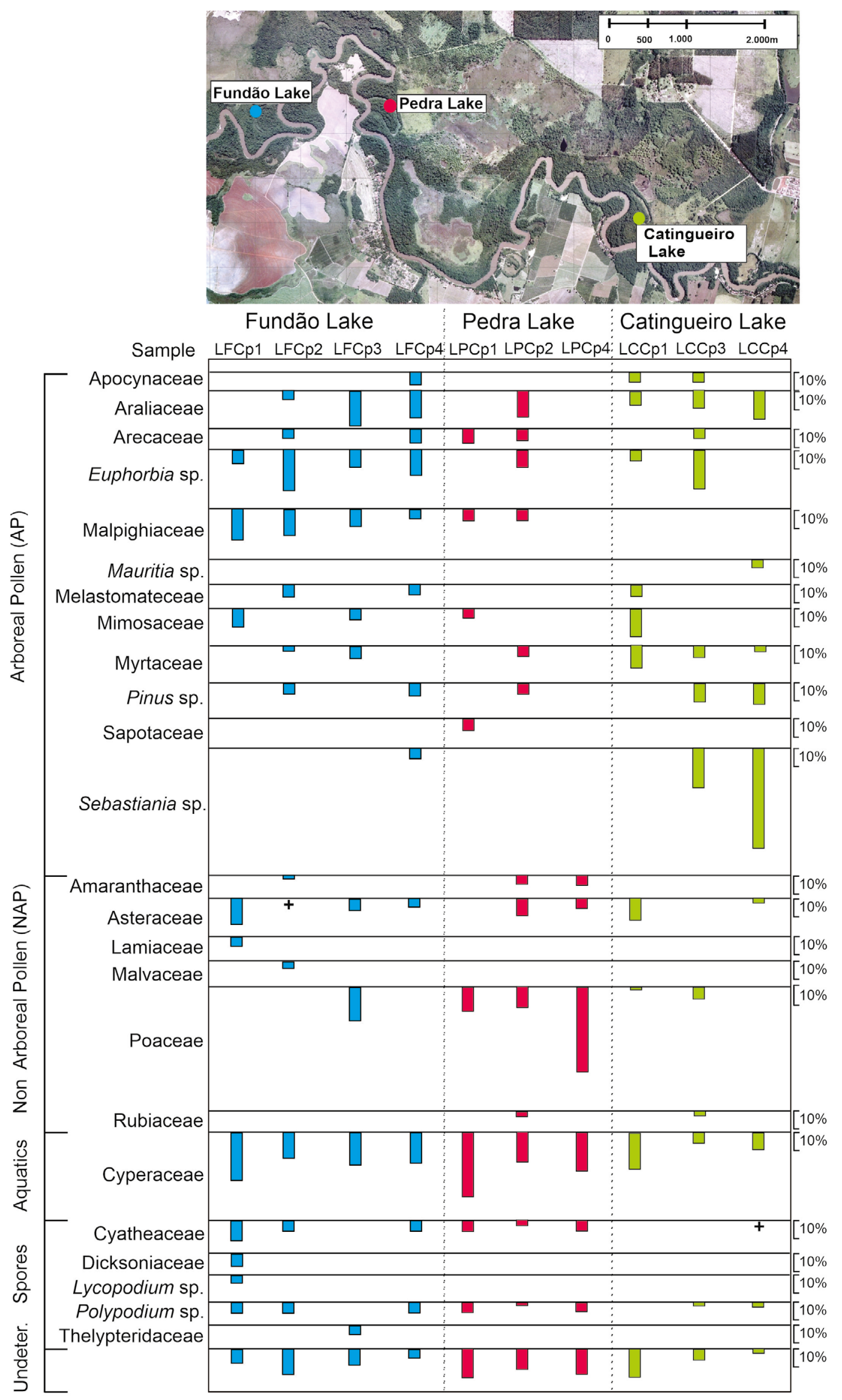

Figure 2. Pollen diagram of Modern Pollen Rain at Mogi Guaçu Ecological Station (MGES). Fundão Lake pollen rain in blue, Pedra Lake modern pollen rain in red, and Catingueiro Lake pollen rain in green (modified Ricardi-Branco et al., 2015). 


\section{ANALYSIS OF LACUSTRINE SEDIMENTS}

\section{Fundão Lake}

Core description. The core depth reached $179 \mathrm{~cm}$. From 0 to $18 \mathrm{~cm}$, sandy-clay sediments, little compressed with presence of roots with 2-4 mm diameter, brown color. From 18 to $33 \mathrm{~cm}$, clay sediments, sparse roots with 1-2 mm diameter, light gray color. 33 to $47 \mathrm{~cm}$, sandy-clay sediments, little compressed, and roots with average diameter of $2-4 \mathrm{~mm}$, brown color. From 47 to $83 \mathrm{~cm}$, clay sediments, scarce roots with diameter of 1-2 $\mathrm{mm}$, light gray color. From 83 to $104 \mathrm{~cm}$, sandy sediments with gravel and light gray color, 104 to $126 \mathrm{~cm}$, sandy sediments, and light gray color. From 126 to $160 \mathrm{~cm}$, sandy sediments with gravel and light gray color. From 160 to $179 \mathrm{~cm}$, sandy sediments, and light gray color (Figure 3).

Chronology. Eleven samples were collected for chronological analysis (Table 1). The results obtained by ${ }^{14} \mathrm{C}$ dating indicate age inversion from the depth of 80 to $179 \mathrm{~cm}$. Between 20 to $80 \mathrm{~cm}$ deep, the ages are in chronological order, however, palynomorphs are absent between the levels. Thus, in the paleoenvironmental interpretation, we decided to use the upper levels between 0 and $20 \mathrm{~cm}$, which presented an age years of 2,730 years cal BP.

Stable nitrogen and carbon isotopes. The $\delta^{13} \mathrm{C}$ ranged between $-16.45 \%$ and $-24.39 \%$, indicating a predominance of $\mathrm{C}_{3}$ plants (forest) in the core (Table 2). The values ${ }^{15} \mathrm{~N}$ were between $5.27 \%$ and $18.94 \%$, strengthening the inferences from the $\delta^{13} \mathrm{C}$ data indicating the predominance of terrestrial plants (Pessenda et al., 1998).
Charcoals. The frequencies for the four levels $(4-6 \mathrm{~cm}, 6-8 \mathrm{~cm}$, $12-14 \mathrm{~cm}, 18-20 \mathrm{~cm}$ depth) follow the chronological sequence, and present palynomorphs (Table 3 ).

Palynological analysis. Ten levels out of the 18 studied are sterile. Eight levels show pollen grains and spores, and four of them $(2-4 \mathrm{~cm}, 6-8 \mathrm{~cm}, 14-16 \mathrm{~cm}, 18-20 \mathrm{~cm}$ depth) were used in paleoenvironmental interpretation, due to the inversion of ages in the core. Those levels show no age inversion to accomplish a more reliable interpretation. Among the recovered palynomorphs, 33 different pollen types are observed, totaling 882 pollen grains. Six hundred and four correspond to tree pollen grains (AP), 271 grains of non-tree pollen (NAP), and seven to grains of undetermined pollens; 51 spores and 182 related to aquatic taxa were identified and counted separately (Figure 4). After analysis, one interval of the core was characterized (Lf1) and described below.

Lf1 Interval (four samples, 20-4 cm depth, 2,730-105 BP). It presents high diversity of arboreal taxa (76\% to $60 \%)$ in three depths (16-4 cm) compared to herbaceous taxa with slight predominance of NAP (52\%) at the lower level. The most frequent arboreal pollen taxa are represented by Araliaceae ( $8 \%$ to $14 \%$ ), Arecaceae (1\% to $7 \%$ ), and Euphorbiaceae [Sebastiania sp. (17\%)]. The presence of Pinus sp. in the superficial level (4-6 cm deep) represents an exotic species. The herbaceous taxa were less diverse. Types with great abundance belong to Poaceae, Asteraceae, Malpighiaceae (Peixotoa sp.), and Amaranthaceae (Gomphrena sp.). The spores present $(\leq 4 \%)$, belong to Cyatheaceae, Dicksoniaceae and Thelypteridaceae (Thelypteris sp.).

Table 1. Radiocarbon dating of sediments collected at Catingueiro, Pedra, and Fundão lakes. Levels and ages used in paleoenvironmental interpretation in bold.

\begin{tabular}{|c|c|c|c|c|}
\hline Local & Depth $(\mathrm{cm})$ & Sample $/ n^{\circ}$ Beta & Conventional ${ }^{14} \mathrm{C}$ Age (BP) & HPD Calibration@95.4\% Probability \\
\hline \multirow[t]{4}{*}{$\begin{array}{l}\text { Catingueiro } \\
\text { Lake }\end{array}$} & $2-4 \mathrm{~cm}$ & Beta-314736 & $300 \pm 30 \mathrm{BP}$ & $\begin{array}{l}(52.7 \%) 1616-1671 \mathrm{cal} \text { AD }(334-279 \mathrm{cal} \mathrm{BP}) \\
(39.1 \%) 1504-1590 \mathrm{cal} \mathrm{AD}(446-360 \mathrm{cal} \mathrm{BP}) \\
(2.4 \%) 1782-1795 \mathrm{cal} \mathrm{AD}(168-155 \mathrm{cal} \mathrm{BP}) \\
(1.2 \%) 1747-1756 \mathrm{cal} \mathrm{AD}(203-194 \mathrm{cal} \mathrm{BP})\end{array}$ \\
\hline & $56-58 \mathrm{~cm}$ & Beta-314737 & $270 \pm 30 \mathrm{BP}$ & $\begin{array}{l}(53 \%) 1625-1679 \mathrm{cal} \mathrm{AD}(325-271 \mathrm{cal} \mathrm{BP}) \\
(38.7 \%) 1732-1800 \mathrm{cal} \text { AD }(218-150 \mathrm{cal} \mathrm{BP}) \\
(3.7 \%) 1514-1542 \mathrm{cal} \text { AD }(436-408 \mathrm{cal} \mathrm{BP})\end{array}$ \\
\hline & $90-92 \mathrm{~cm}$ & Beta-314738 & $260 \pm 30 \mathrm{BP}$ & $\begin{array}{l}(50.8 \%) 1730-1803 \mathrm{cal} \text { AD }(220-147 \mathrm{cal} \mathrm{BP}) \\
(44.6 \%) 1628-1682 \mathrm{cal} \text { AD ( } 322-268 \mathrm{cal} \mathrm{BP})\end{array}$ \\
\hline & $150-152 \mathrm{~cm}$ & Beta-322766 & $2.830 \pm 30 \mathrm{BP}$ & $(95.4 \%) 1020-835 \mathrm{cal} \mathrm{BC}(2969-2784 \mathrm{cal} \mathrm{BP})$ \\
\hline \multirow[t]{4}{*}{ Pedra Lake } & $2-4 \mathrm{~cm}$ & Beta-314742 & $105.6 \pm 0.3 \mathrm{pMC}$ & SEE OxCAL Calibration \\
\hline & $46-49 \mathrm{~cm}$ & Beta-314743 & $510 \pm 30 \mathrm{BP}$ & $(95.4 \%) 1408-1458 \mathrm{cal} \mathrm{AD}(542-492 \mathrm{cal} \mathrm{BP})$ \\
\hline & $73-75 \mathrm{~cm}$ & Beta-322771 & $1780 \pm 30 \mathrm{BP}$ & (95.4\%) 231-375 cal AD (1719-1575 cal BP) \\
\hline & $96-98 \mathrm{~cm}$ & Beta-314744 & $1800 \pm 30 \mathrm{BP}$ & (95.4\%) 210-364 cal AD (1740-1586 cal BP) \\
\hline \multirow{11}{*}{$\begin{array}{l}\text { Fundão } \\
\text { Lake }\end{array}$} & $2-4 \mathrm{~cm}$ & Beta-314739 & $105.2 \pm 0.3 \mathrm{pMC}$ & SEE OxCAL Calibration \\
\hline & $16-18 \mathrm{~cm}$ & Beta-335496 & $2.730 \pm 30 \mathrm{BP}$ & $(95.4 \%) 906-800 \mathrm{cal} \mathrm{BC}(2855-2749 \mathrm{cal} \mathrm{BP})$ \\
\hline & $30-33 \mathrm{~cm}$ & Beta-314740 & $11.420 \pm 60 \mathrm{BP}$ & (95.4\%) 11395-11133 cal BC (13344-13082 cal BP) \\
\hline & $45-47 \mathrm{~cm}$ & Beta-329466 & $11.890 \pm 50 \mathrm{BP}$ & $(95.4 \%) 11826-11601 \mathrm{cal} \mathrm{BC}(13775-13550 \mathrm{cal} \mathrm{BP})$ \\
\hline & $49-51 \mathrm{~cm}$ & Beta-335497 & $20.420 \pm 80 \mathrm{BP}$ & (95.4\%) 22915-22251 cal BC (24864-24200 cal BP) \\
\hline & $81-83 \mathrm{~cm}$ & Beta-314741 & $27.330 \pm 150 \mathrm{BP}$ & (95.4\%) 29466-29034 cal BC (31415-30983 cal BP) \\
\hline & $92-94 \mathrm{~cm}$ & Beta-335498 & $6.220 \pm 40 \mathrm{BP}$ & $\begin{array}{l}(92 \%) 5230-4998 \mathrm{cal} \mathrm{BC}(7179-6947 \mathrm{cal} \mathrm{BP}) \\
(3.4 \%) 5290-5251 \mathrm{cal} \mathrm{BC} \mathrm{(7239-7200} \mathrm{cal} \mathrm{BP)}\end{array}$ \\
\hline & $105-107 \mathrm{~cm}$ & Beta-329467 & $19.060 \pm 80 \mathrm{BP}$ & $(95.4 \%) 21226-20635 \mathrm{cal} \mathrm{BC}(23175-22584 \mathrm{cal} \mathrm{BP})$ \\
\hline & $128-130 \mathrm{~cm}$ & Beta-322767 & $6.660 \pm 40 \mathrm{BP}$ & (95.4\%) 5623-5487 cal BC (7572-7436 cal BP) \\
\hline & $144-146 \mathrm{~cm}$ & Beta-335499 & $7.750 \pm 40 \mathrm{BP}$ & $\begin{array}{l}(71.8 \%) 6452-6328 \mathrm{cal} \mathrm{BC}(8401-8277 \mathrm{cal} \mathrm{BP}) \\
(23.6 \%) 6319-6252 \mathrm{cal} \mathrm{BC}(8268-8201 \mathrm{cal} \mathrm{BP})\end{array}$ \\
\hline & $160-162 \mathrm{~cm}$ & Beta-322768 & $13.310 \pm 50 \mathrm{BP}$ & (95.4\%) 14199-13797 cal BC (16148-15746 cal BP) \\
\hline
\end{tabular}




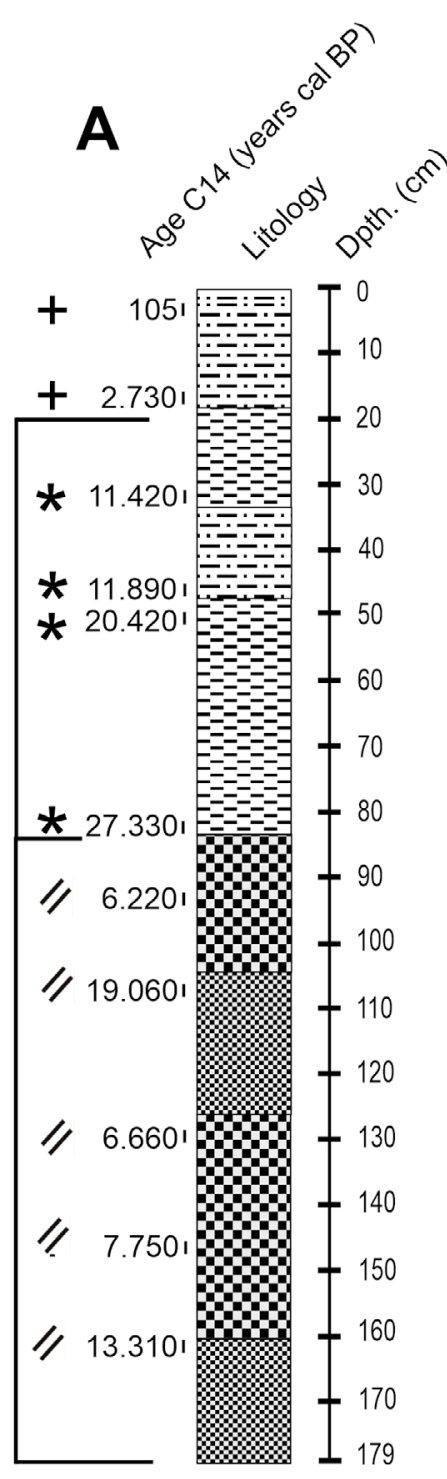

Fundão Lake

\section{L.egend}

Dandy interval
Dark sandy interval with gravel and mica
Dark sandy interval with mica
Gray sandy clayey interval

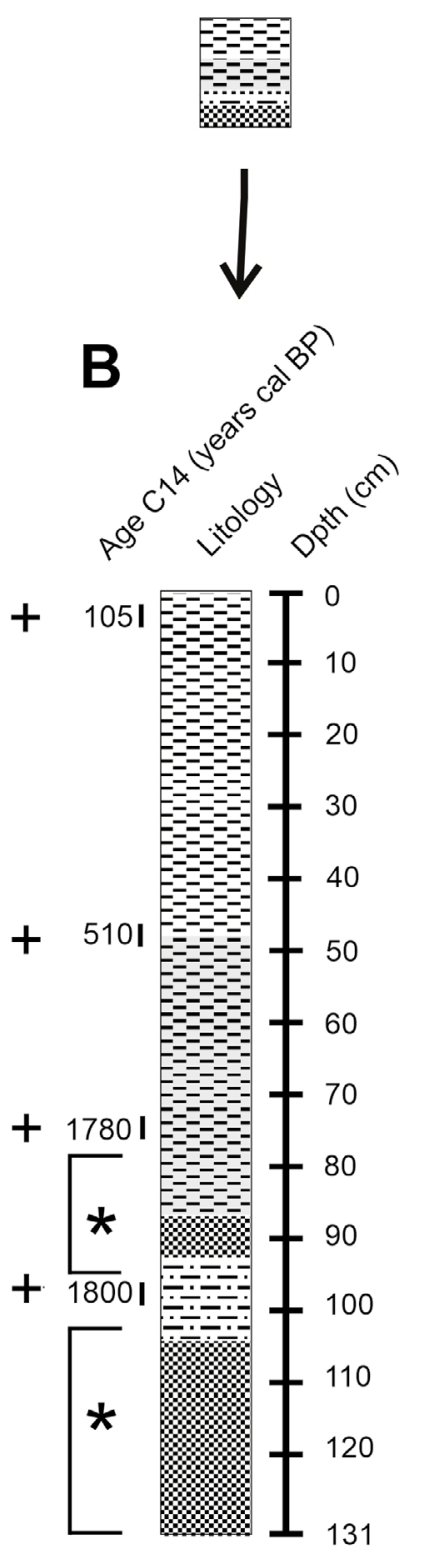

Pedra Lake

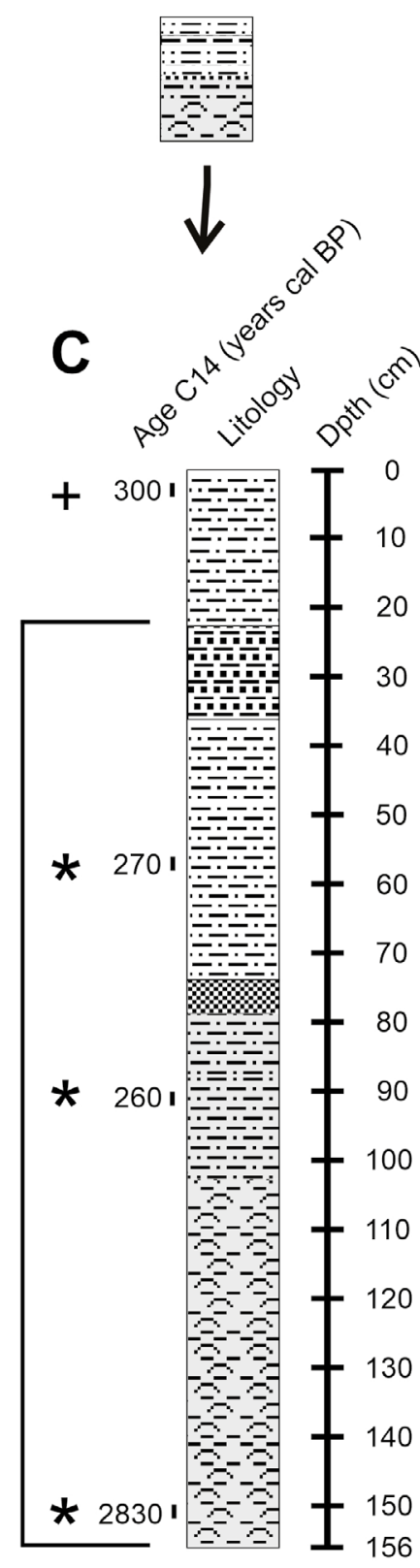

Catingueiro Lake
E=-=-二-4 Clayey interval

E=:=-- Dark clay with mica interval

Sandy clay interval

Light gray clay with leaves interval
${ }^{1}$ Inverted ages

+ Fertile levels * Sterile levels

Figure 3. Core lithologies of the studied locations at Mogi Guaçu Ecological Station (MGES): A, Fundão Lake; B, Pedra Lake; C, Catingueiro Lake. 


\section{Pedra Lake}

Core description. The core depth reached $131 \mathrm{~cm}$. From 0 to $48 \mathrm{~cm}$, clay sediments, roots with $2-3 \mathrm{~mm}$ diameter, brown color. From 48 to $87 \mathrm{~cm}$, micaceous sandy-clay sediments, little compressed, light brown color. From 87 to $92 \mathrm{~cm}$, coarse sandy and poorly selected, light yellowish color. From 92 to $101 \mathrm{~cm}$, sandy-clay sediments, poorly compressed, light brown color. From 101 to $131 \mathrm{~cm}$, coarse sand poorly selected, light yellowish color (Figure 3).

Chronology. It was carried out in four levels: $2-4 \mathrm{~cm}, 46-49$ $\mathrm{cm}, 73-75 \mathrm{~cm}$, and $96-98 \mathrm{~cm}$. The ${ }^{14} \mathrm{C}$ ages increase according to depth, without inversion. The data show that the sediments were deposited during the last 1,800 years cal BP (Table 1). Stable nitrogen and carbon isotopes. Values of $\delta^{13} \mathrm{C}$ are between $-21.65 \%$ and $26.64 \%$, showing the predominance of $\mathrm{C}_{3}$ plants (forest) in the profile. The values of ${ }^{15} \mathrm{~N} /{ }^{14} \mathrm{~N}$ ratio vary between $6.21 \%$ and $10.72 \%$, indicating the prevalence of algae (Table 2).

Charcoals. To obtain the fire frequency, samples of 25 levels were analyzed and charcoal fragments were obtained in 17 (Table 3). For paleoenvironmental interpretation, we used the same levels where palynomorphs were found $(4-6 \mathrm{~cm}$, $18-20 \mathrm{~cm}, 26-28 \mathrm{~cm}, 32-34 \mathrm{~cm}, 38-40 \mathrm{~cm}, 46-48 \mathrm{~cm}, 51-53$ $\mathrm{cm}, 57-59 \mathrm{~cm}, 67-69 \mathrm{~cm}, 73-75 \mathrm{~cm}$, and 96-98 cm depth). Palynological analysis. The study of 13 levels $(4-6 \mathrm{~cm}$, $12-14 \mathrm{~cm}, 18-20 \mathrm{~cm}, 26-28 \mathrm{~cm}, 32-34 \mathrm{~cm}, 38-40 \mathrm{~cm}, 46-48$ $\mathrm{cm}, 51-53 \mathrm{~cm}, 57-59 \mathrm{~cm}, 61-63 \mathrm{~cm}, 67-69 \mathrm{~cm}, 73-75 \mathrm{~cm}$, and $96-98 \mathrm{~cm}$ depth) showed quantitative and qualitative variations in types of pollen (Figure 5). The total recovered palynomorphs showed 69 pollen types, in 1,666 pollen grains. 839 correspond to grains of tree pollen (AP), 722 to grains of non-tree pollen (NAP), and 55 are undetermined. 209 spores and 478 aquatics were identified and counted separately. After analysis, three intervals for the core (Lp1, Lp2 and Lp3) were characterized. The intervals were separated according to the frequency and variety of pollen grains over the core, and age obtained in the dated samples. The description of each interval is presented below.

Lp1 Interval (one sample, 98-96 cm depth, 1,800 BP) is characterized by high concentration of pollen grains, and lack of spores. Among the arboreal taxa, the types belong to Arecaceae, Malpighiaceae, Euphorbiaceae, Melastomataceae, Fabaceae/Mimosaceae (Dalbergia sp., Copaifera sp., Pterocarpus sp., and Mimosa sp.). Among the herbaceous taxa, there are Asteraceae, Poaceae, Rubiaceae (Borreria sp.), and Amaranthaceae (Gomphrena sp., Amaranthus sp. and Alternanthera sp.). The Cyperaceae dominate aquatic or water level related taxa.

Lp2 Interval (nine samples, $75-32 \mathrm{~cm}$ depth, 1,780-510 BP) is characterized by the appearance of spores in the core, as well as the presence of Mauritia sp. (Arecaceae), which characterize the Riparian Forest, and Curatella sp. (Dilleniaceae), which indicates the presence of the Cerradão Forest. The percentage of herbaceous taxa [Bromeliaceae, Poaceae, Amaranthaceae (Gomphrena sp.), and Asteraceae $(60 \%)$ ] increases when compared to Lp1 interval, while the presence of arboreal taxa decreases (55\%). Among the arboreal taxa, it is highlighted the presence of Arecaceae,

Table 2. Results of $\delta^{13} \mathrm{C}$ and $\delta^{15} \mathrm{~N}$ found in cores studied for Fundão, Pedra, and Catingueiro lakes at MGES. Levels and ages used in paleoenvironmental interpretation in bold.

\begin{tabular}{|c|c|c|c|c|c|c|c|c|}
\hline \multicolumn{3}{|c|}{ Catingueiro } & \multicolumn{3}{|c|}{ Pedra } & \multicolumn{3}{|c|}{ Fundão } \\
\hline $\begin{array}{r}\text { Depth } \\
(\mathrm{cm})\end{array}$ & $\begin{array}{r}\delta^{13} \mathrm{C} \\
(\% 0)\end{array}$ & $\begin{array}{r}{ }^{15} \mathrm{~N} \\
(\%)\end{array}$ & $\begin{array}{r}\text { Depth } \\
(\mathrm{cm})\end{array}$ & $\begin{array}{l}\delta^{13} \mathrm{C} \\
(\%)\end{array}$ & $\begin{array}{r}{ }^{15} \mathrm{~N} \\
(\% 0)\end{array}$ & $\begin{array}{r}\text { Depth } \\
(\mathrm{cm})\end{array}$ & $\begin{array}{r}\delta^{13} \mathrm{C} \\
(\% 0)\end{array}$ & $\begin{array}{r}{ }^{15} \mathrm{~N} \\
(\%)\end{array}$ \\
\hline 0-2 & -24.08 & 3.14 & $0-2$ & -26.64 & 7.3 & 0-2 & -23.99 & 9.47 \\
\hline $2-4$ & - & - & $2-4$ & -25.95 & 5.97 & $2-4$ & - & - \\
\hline $10-12$ & -24.07 & 4.16 & $10-12$ & -26.13 & 6.99 & $10-12$ & -24.02 & 6.74 \\
\hline $20-22$ & -28.40 & 0.93 & $20-22$ & -22.74 & 6.66 & $20-22$ & -24.39 & 5.27 \\
\hline $30-32$ & -24.21 & -1.23 & 30-32 & -25.14 & 6.21 & $30-33$ & -21.43 & 14.77 \\
\hline $40-42$ & -24.58 & 12.64 & $40-42$ & -23.12 & 8.7 & $39-41$ & -18.59 & - \\
\hline $50-52$ & -27.53 & 3.04 & $49-51$ & -22.01 & 9.13 & $49-51$ & -20.42 & 10.11 \\
\hline $60-62$ & -29.17 & 1.81 & $59-61$ & -21.65 & 7.6 & $59-61$ & -17.60 & - \\
\hline $70-12$ & -28.09 & -2.76 & $69-71$ & -22.49 & 7.78 & $69-71$ & -16.65 & - \\
\hline $80-82$ & -28.42 & -3.03 & $79-81$ & -23.9 & 10.72 & $81-83$ & -16.88 & - \\
\hline $90-92$ & -29.23 & -0.92 & 89-91 & -25.59 & - & 89-91 & -16.45 & - \\
\hline $100-102$ & -26.43 & -4.55 & 91-93 & -26 & - & 99-100 & -21.17 & 9.76 \\
\hline $110-112$ & -25.33 & 4.28 & $100-102$ & -24.93 & - & 109-111 & -18.56 & - \\
\hline $120-122$ & -25.46 & 7.81 & 110-112 & -25.15 & - & $119-121$ & -16.81 & - \\
\hline $130-132$ & -25.63 & 13.18 & $120-122$ & -25.49 & - & $130-132$ & -17 & - \\
\hline $140-142$ & -26.64 & - & & & & $140-142$ & -19.07 & - \\
\hline $150-152$ & -26.09 & - & & & & $150-152$ & -19.47 & 18.94 \\
\hline \multirow[t]{2}{*}{$160-162$} & -26.09 & - & & & & $160-162$ & -18.89 & - \\
\hline & & & & & & $170-172$ & -18.26 & - \\
\hline
\end{tabular}


Table 3. Depth, number of charcoal fragments (charcoals) and their mean sizes in the three cores. Levels and ages used in paleoenvironmental interpretation in bold.

\begin{tabular}{|c|c|c|c|c|c|c|c|c|}
\hline \multicolumn{3}{|c|}{ Catingueiro } & \multicolumn{3}{|c|}{ Pedra } & \multicolumn{3}{|c|}{ Fundão } \\
\hline $\begin{array}{l}\text { Depth } \\
(\mathrm{cm})\end{array}$ & $\begin{array}{l}\text { Fragment } \\
\text { Number }\end{array}$ & $\begin{array}{l}\text { Average size } \\
\quad(\mathrm{mm})\end{array}$ & $\begin{array}{l}\text { Depth } \\
(\mathrm{cm})\end{array}$ & $\begin{array}{l}\text { Fragment } \\
\text { Number }\end{array}$ & $\begin{array}{l}\text { Average size } \\
\quad(\mathrm{mm})\end{array}$ & $\begin{array}{l}\text { Depth } \\
(\mathrm{cm})\end{array}$ & $\begin{array}{l}\text { Fragment } \\
\text { Number }\end{array}$ & $\begin{array}{l}\text { Average size } \\
(\mathrm{mm})\end{array}$ \\
\hline $4-6$ & 19 & 463 & $4-6$ & 21 & 3880 & 04-06 & 9 & 200 \\
\hline 8-10 & 23 & 843 & $6-8$ & 18 & 860 & $06-08$ & 11 & 700 \\
\hline $14-16$ & 15 & 664 & $18-20$ & 25 & 1200 & $14-16$ & 10 & 2500 \\
\hline $34-36$ & 17 & 1750 & $26-28$ & 19 & 540 & $28-30$ & 19 & 267 \\
\hline $38-40$ & 16 & 1767 & $32-34$ & 26 & 340 & $35-37$ & 7 & 400 \\
\hline $42-44$ & 19 & 1425 & $38-40$ & 26 & 343 & $37-39$ & 10 & 600 \\
\hline $46-48$ & 26 & 2167 & $42-44$ & 13 & 975 & $43-45$ & 6 & 450 \\
\hline $52-54$ & 18 & 1150 & $46-48$ & 14 & 367 & $53-55$ & 13 & 533 \\
\hline $62-64$ & 15 & 1463 & $51-53$ & 20 & 433 & $57-59$ & 14 & 1420 \\
\hline $82-84$ & 8 & 850 & $57-59$ & 12 & 325 & $63-65$ & 22 & 2138 \\
\hline $88-90$ & 23 & 720 & $67-69$ & 18 & 1250 & $73-75$ & 5 & 200 \\
\hline $92-94$ & 16 & 838 & $73-75$ & 24 & 640 & $93-95$ & 10 & 433 \\
\hline $94-96$ & 21 & 1750 & $77-79$ & 29 & 429 & 107-109 & 19 & 1780 \\
\hline $96-98$ & 12 & 2000 & $83-85$ & 26 & 317 & $128-130$ & 17 & 150 \\
\hline $102-104$ & 18 & 1186 & 96-98 & 14 & 980 & $148-150$ & 15 & 150 \\
\hline $106-108$ & 22 & 738 & $112-114$ & 15 & 500 & $156-158$ & 8 & 400 \\
\hline $122-124$ & 17 & 1100 & $114-116$ & 19 & 500 & $162-164$ & 15 & 500 \\
\hline $128-130$ & 15 & 1317 & & & & $164-168$ & 14 & 450 \\
\hline
\end{tabular}

Apocynaceae, Malpighiaceae, Myrtaceae, and Sapindaceae. In addition to the genera Sebastiania (Euphorbiaceae), Mimosa (Fabaceae/Mimosaceae), and Copaifera (Fabaceae), there are spores characterized by the genera Cyathea (Cyatheaceae), Polypodium (Polypodiaceae), Thelypteris sp. (Thelypteridaceae), and the family Dicksoniaceae.

Lp3 Interval (four samples, 28-4 cm depth, 510-105 BP) is characterized by the decrease in pollen grains $(\leq 280)$, and the absence of Mauritia sp., which was present in Lp2. However, other pollen grains of the Arecaceae were found ( $4 \%$ to $9 \%)$. It is relevant the predominance of herbaceous taxa compared to arboreal pollen taxa. Among the arboreal taxa, the Myrtaceae (13\%), Araliaceae (10\%), Anacardiaceae (7\%), Aquifoliaceae [llex sp. (10\%)] and Euphorbiaceae $(6 \%)$ are found in high percentages, and Sebastiania sp. (15\%) is the most relevant. The herbaceous taxa are characterized by the high percentage of Asteraceae (28\%), Poaceae (29\%), Rubiaceae (11\%), and Chenopodiaceae [Chenopodium sp. $(10 \%)]$. The family Bromeliaceae shows a slight decrease (3\%) compared to Lp2 Interval. There is a low frequency of spores (6\%) as Cyathea sp. (Cyatheaceae), Schizaea sp. (Schizaeaceae), and Thelypteris sp. (Thelypteridaceae).

\section{Catingueiro Lake}

Core description. The core depth reached $156 \mathrm{~cm}$. From 0 to $23 \mathrm{~cm}$, sandy-clay sediments, little compressed, roots of diameter $2-5 \mathrm{~mm}$, brown color. 23 to $3 \mathrm{~cm}$, sandy-clay sediments, poorly compressed, roots with 1-2 mm diameter, light brown color. From 36 to $74 \mathrm{~cm}$, sandy-clay sediments, little compressed, roots with diameter of $2-5 \mathrm{~mm}$, brown color. From 74 to $79 \mathrm{~cm}$, medium to fine sand, micaceous, yellowish color. From 79 to $102 \mathrm{~cm}$, clay sediments, leaf remains, light gray color. From 102 to $156 \mathrm{~cm}$, clay sediments, fragments of leaves and light gray color (Figure 3).

Chronology. Dating was performed for levels $2-4 \mathrm{~cm}$, $56-58 \mathrm{~cm}, 90-92 \mathrm{~cm}$, and $150-152 \mathrm{~cm}$ in the profile base (Table 1). However, for the paleoenvironmental interpretation was used only the $2-4 \mathrm{~cm}$ depth, obtaining the age years 300 years cal BP.

Stable nitrogen and carbon isotopes. The $\delta^{13} \mathrm{C}$ values fluctuated between $-24.07 \%$ and $-29.23 \%$, featuring the predominance of $\mathrm{C}_{3}$ plants (forest). The values of ${ }^{15} \mathrm{~N}$ ratio changed from $-3.03 \%$ to $13.18 \%$ indicating that most organic matter in the profile comes from algae (Table 2).

Charcoals. Charcoal fragments were found in the 18 levels analyzed in Catingueiro Lake (Table 3). However, for paleoenvironmental interpretation, only levels with pollen grains were used $(4-6 \mathrm{~cm}, 8-10 \mathrm{~cm}, 14-16 \mathrm{~cm}$ depth).

Palynological analysis. Among the 17 levels analyzed, pollen grains and spores were found at levels $4-6 \mathrm{~cm}$ and $14-16 \mathrm{~cm}$ (Figure 6). Of the total sum of recovered palynomorphs, 19 pollen types were observed, totaling 303 pollen grains; 167 correspond to grains of tree pollen (AP), 122 to grains of non-tree pollen (NAP), and 14 are undetermined; 43 spores and 55 aquatic spores were identified and counted separately. After analysis, one interval (Lc1) was characterized and described below. Depth $16-14 \mathrm{~cm}$ is characterized by high concentration of pollen and spores, totaling 205 pollen grains: 143 grains of tree pollen, 52 non-tree, and 10 undetermined. 37 spores and 54 types of the aquatic. Among the arboreal 


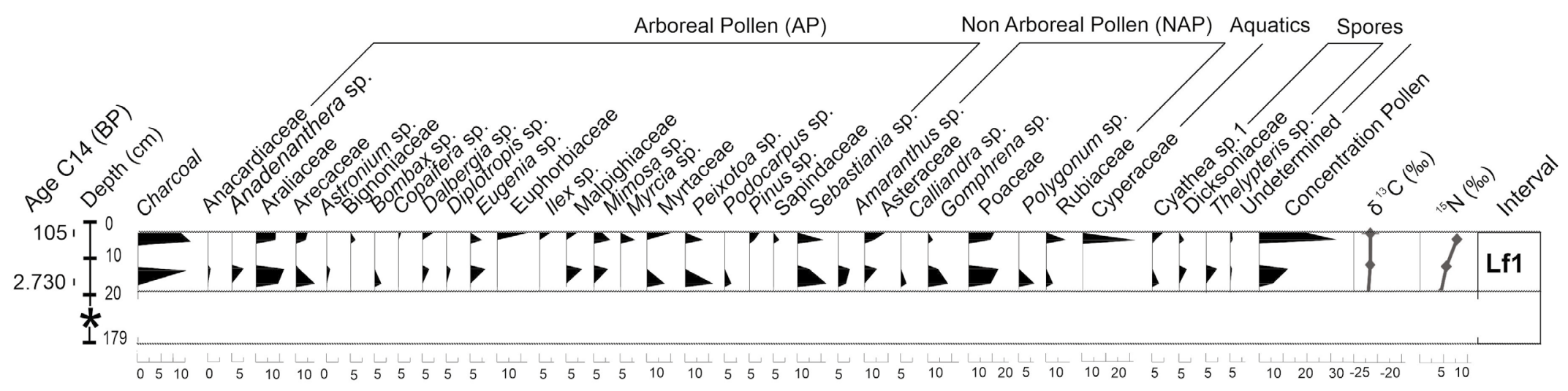

Legend:

* Levels cut because they do not have palinomorphs (sterile) and contain inverted ages

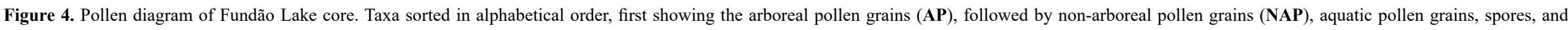
indeterminated.

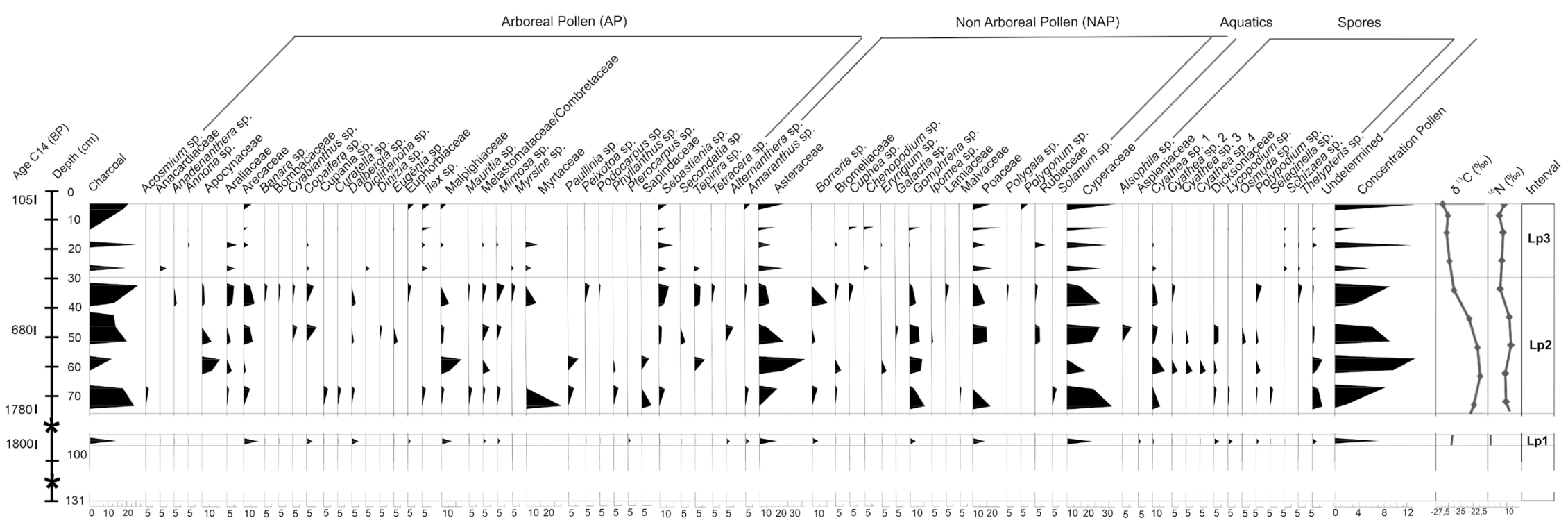

Legend

* Levels cut because they do not have palinomorphs (sterile)

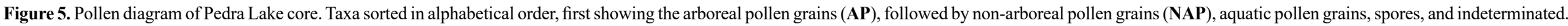




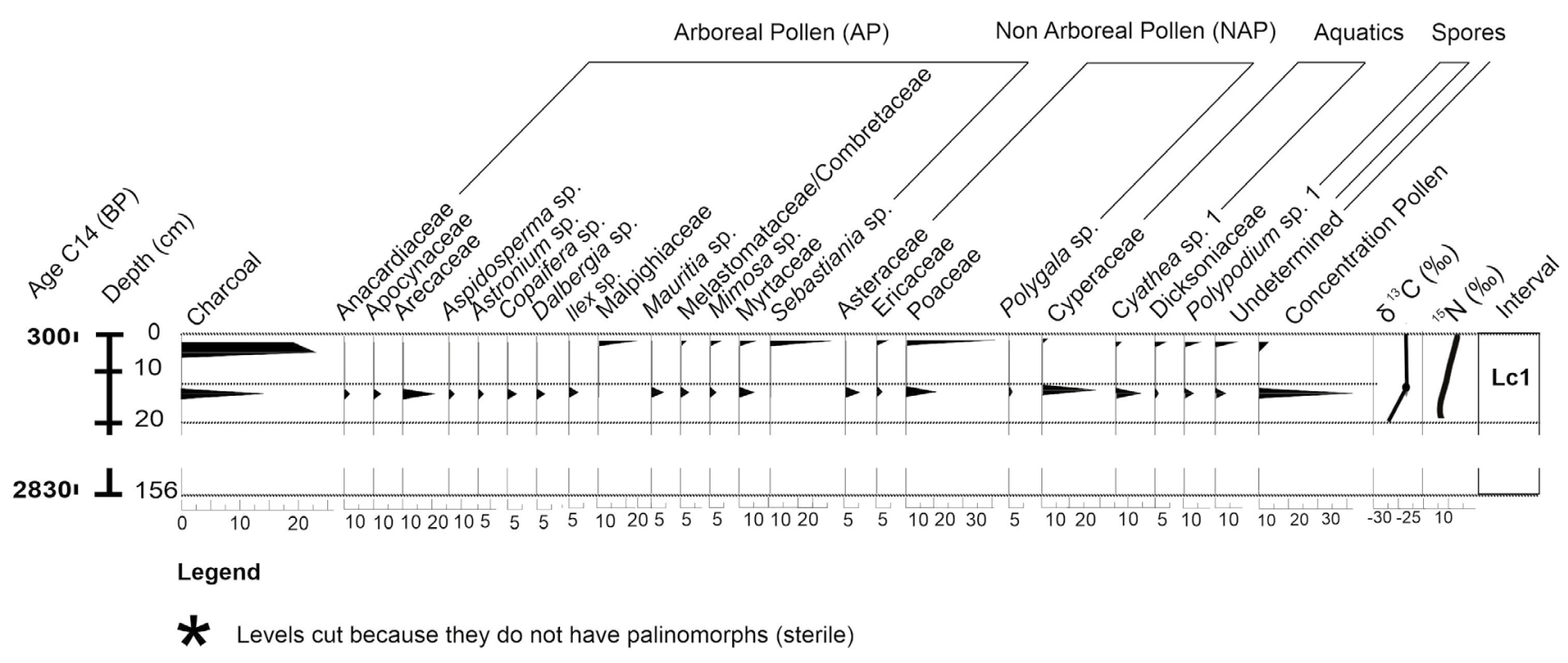

Figure 6. Pollen diagram of Catingueiro Lake core. Taxa sorted in alphabetical order, first showing the arboreal pollen grains (AP), followed by non-arboreal pollen grains (NAP), aquatic pollen grains, spores, and indeterminated.

taxa, significant pollen grains of Mauritia sp. (5\%) indicate the presence of Riparian Forest in the area. The Araliaceae comes next (10\%), followed in abundance by Myrtaceae, Melastomataceae, Aquifoliaceae (Ilex sp.), Anarcardiaceae (Astronium sp.), Apocynaceae (Aspidosperma sp.), and Fabaceae/Mimosaceae (Mimosa sp.). Among herbaceous taxa, the presence of Poaceae is significant, followed by Asteraceae and Ericaceae. The aquatic types are represented by the family Cyperaceae. The spores remained constant at level 4-6 (13\%) with Cyatheaceae (Cyathea sp.), Polypodiaceae (Polypodium sp.), and Dicksoniaceae. The most superficial sample, 4-6 depth, is characterized by a low frequency of pollen grains; 24 correspond to arboreal pollen grains, 18 to non-arboreal, and four indeterminated. The spores obtained the sum of six, and one type of aquatic. Among the arboreal taxa, the highest percentage (24\%) presented Sebastiania sp. (Euphorbiaceae), followed by Mimosa sp. (Fabaceae/Minosaceae), Malpighiaceae, Myrtaceae, and Melastomataceae. Non-arboreal taxa had its highest percentage in Poaceae (35\%), followed by Ericaceae (4\%). Regarding the spores, we found few spores of Polypodiaceae (Polypodium sp.), Dicksoniaceae, and Cyatheaceae (Cyathea sp.).

\section{DISCUSSION}

\section{Modern pollen rain}

Regarding the record of modern pollen rain at MGES (Figures 7-9), 24 types were identified out of 1,628 pollen grains, 138 spores, 318 aquatics, and 158 types remain indeterminated. The arboreal pollen represents most of the record with Euphorbiaceae (Euphorbia sp.), Fabaceae, Araliaceae, Myrtaceae, Arecaceae, Sapotaceae, and Pinaceae (Pinus sp.). In relation to herbaceous taxa, the most abundant pollen belongs to Poaceae and Asteraceae families. Among spores, the Cyatheaceae family was the most abundant (Figure
2). We infer that the modern pollen rain collected presents predominant taxa of Semideciduous-Riparian Forests. The pollen rain analysis shows that the predominant elements are the associations corresponding to wetlands near the banks of Mogi Guaçu River. According to data obtained at the site, Fundão Lake presents a significant increase of spores associated with the high local humidity. It was an abandoned meander bend for a long time and a site less affected by high energy events, often responsible for changing vegetation (Ricardi-Branco et al., 2015). Comparing the record with that of Lf1, we observe that in both there is a predominant taxon of Semideciduous-Riparian Forests (e.g. Arecaceae and Myrtaceae) followed by the taxa of those that inhabit the ecotone (e.g. Araliaceae and Malpighiaceae) between the phytophiosionomy and the Cerradão. Pedra Lake shows an increase in the percentage of aquatics, represented by Cyperaceae, a fact that may be related to the proximity to the bank of Mogi Guaçu River, indicating a constant flooding area. When comparing the modern pollen grains with the Lp1 and Lp2 intervals, it is possible to observe that the tree taxa of the families Arecaceae, Araliaceae and Melastomataceae (Semideciduous-Riparian Forest), as well as Malpighiaceae (Ecotone) and Mimosaceae (Cerradão Forest), are common with them. Among NAP, the common taxa refer to ecotone families (Asteraceae, Lamiaceae, and Poaceae) and Semideciduous-Riparian Forest (i.e. Cyathea sp. and Polypodium sp.). There is a difference between modern pollen grain and assemblies of the Lp1 and Lp2 intervals, where occurred the predominance of Cerradão Forest elements. The comparison between the modern pollen rain and the Lp3 showed that both have a common arboreous taxa from the Semideciduous-Riparian Forest (Arecaceae and Myrtaceae) and the Ecotone (Araliaceae, Malpighiaceae). Between the herbaceous taxa, there are specimens of Asteraceae and Poaceae, which represent the ecotone. Catingueiro Lake 

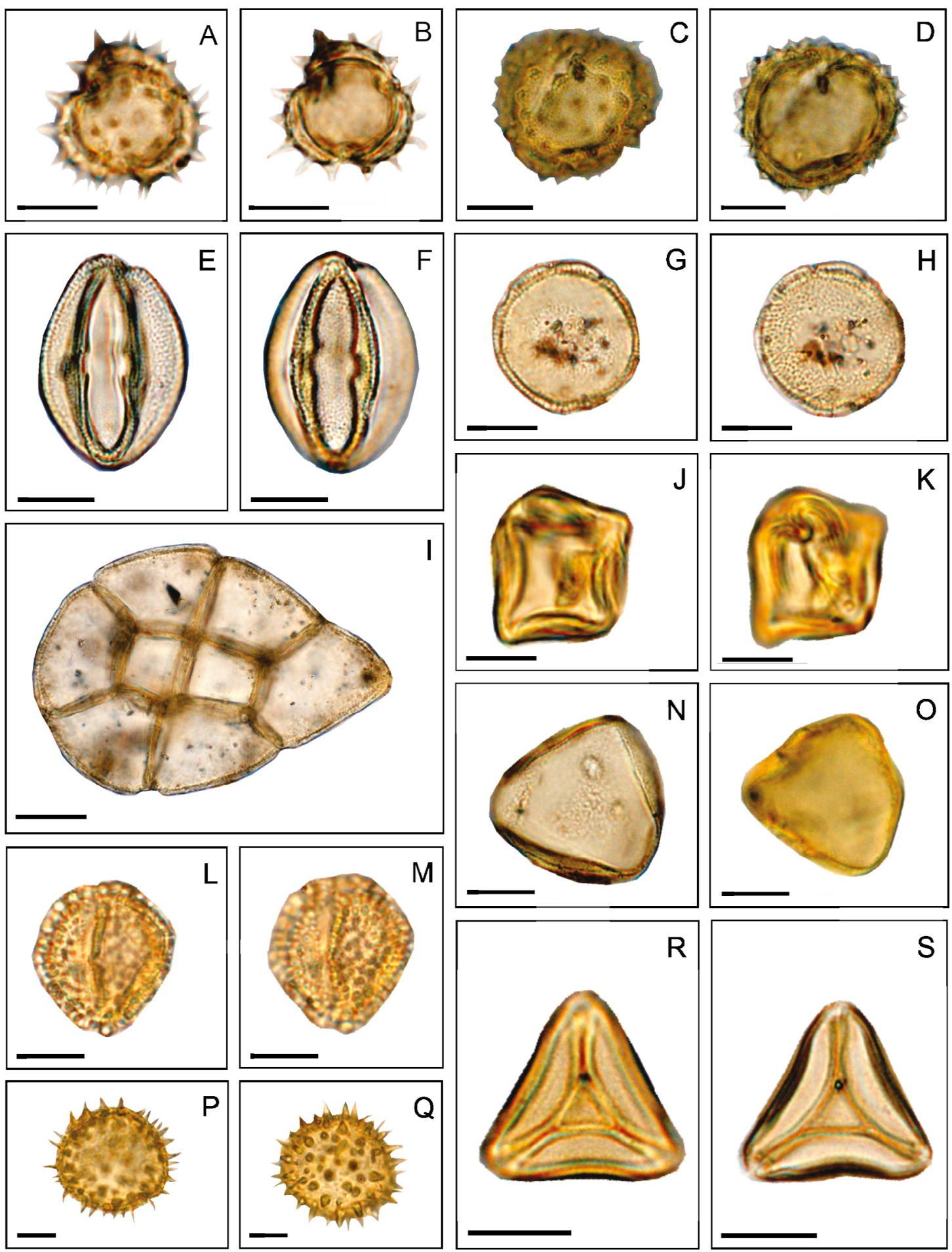

Figure 7. Angiosperm pollen grains observed at Mogi Guaçu Ecological Station (MGES) cores. A-D, Asteraceae; E-F, Euphorbiaceae; G-H, Borreria sp.; I, Calliandra sp.; J-K, Copaifera sp.; L-M, Ilex sp.; N-O, Cyperaceae; P-Q, Mauritia sp.; R-S, Myrtaceae. Scale bars $=10 \mu \mathrm{m}$.

presents significant elements of Semideciduous-Riparian Forest, higher than Cerradão elements. The presence of Mauritia sp., despite its low percentage, contributes to keep the Semideciduous-Riparian Forest with high humidity near the banks of Mogi Guaçu River. When comparing the modern pollen grain with that of Lc1, it is possible to observe in both, the predominance of taxa related to Semideciduous-Riparian Forest remain.
Integration of palynological, isotopic, and fire frequency studies

Studies carried out at the Mogi Guaçu Ecological Station showed changes in the meandering system of the Mogi Guaçu River during the Holocene (Zancopé \& Perez Filho, 2006; Storani \& Perez Filho, 2015). The changes influenced the erosion and depositional processes, as a result of climate change. Zancopé \& Perez Filho (2006) and Storani \& Perez 

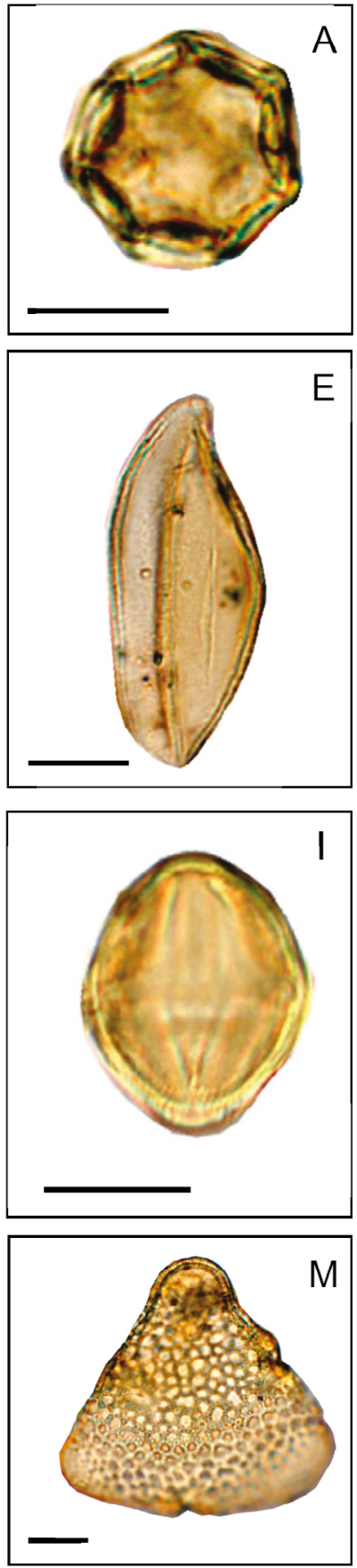
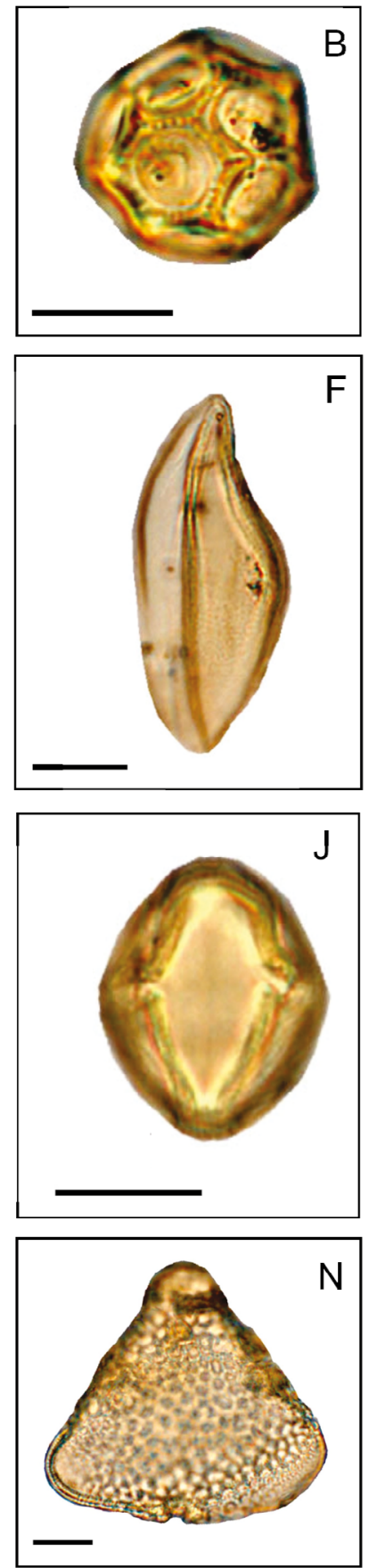
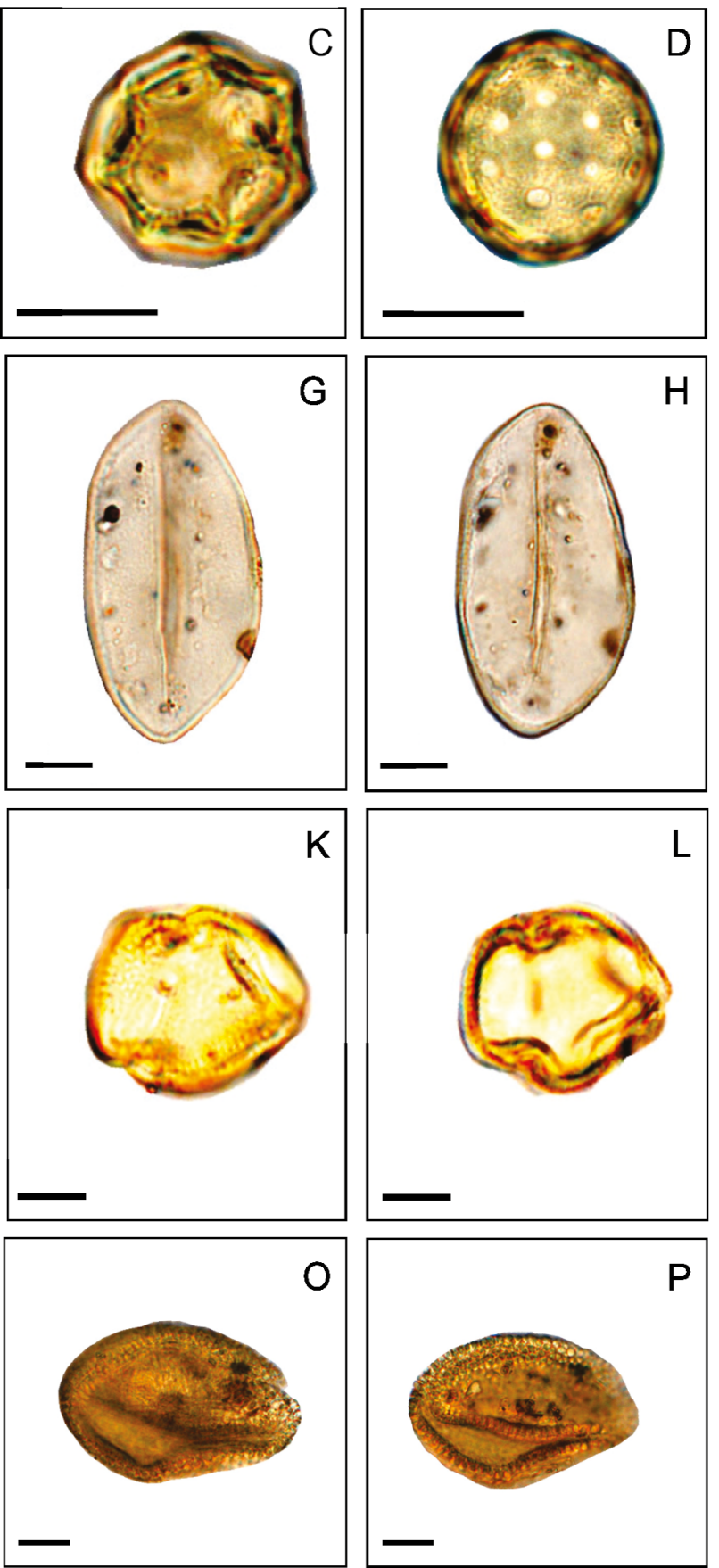

Figure 8. Angiosperm pollen grains observed at Mogi Guaçu Ecological Station (MGES) cores. A-D, Alternathera sp.; E-H, Arecaceae; I-J, Anacardiaceae; $\mathbf{K}-\mathbf{L}$, Araliaceae; M-N, Bombacaceae; $\mathbf{O}-\mathbf{P}$, Bromeliaceae. Scale bars $=10 \mu \mathrm{m}$.

Filho (2015) confirm that the adjustment in the morphology of the river channel promoted the fitting of the abandoned meanders favoring an increase in gradient and causing an increase in the drainage energy. The events may have changed the river dynamics in the area promoting episodes of erosion and redeposition in the three lagoons studied. Thus, it may explain the inversions in ages verified in the depths 179 to $80 \mathrm{~cm}$ in Fundão Lake. The changes/anomalies were before 2,730 years cal BP, which shows stability for the three lakes studied after that date. A representative scheme of vegetation and climate changes was made for the study area over the last
2,730 years cal BP. We classified the vegetation dynamics in three stages from ancient to modern:

- Stage I. The oldest records are represented at the base of Lf1 (Fundão Lake) 2,730 years cal BP with taxa of Arecaceae, Malpighiaceae, Myrtaceae, Euphorbiaceae (Sebastiania sp.), and Cyatheceae (Cyathea sp.) among spores, indicating humid climate with areas of permanent flood and developed Semideciduous-Riparian Forest. The event could have affected the Southwest of Minas Gerais State, where the Mogi Guaçu River spring is located, near Serra da Mantiqueira. It explains the presence of pollen grains, such as Ilex sp., 

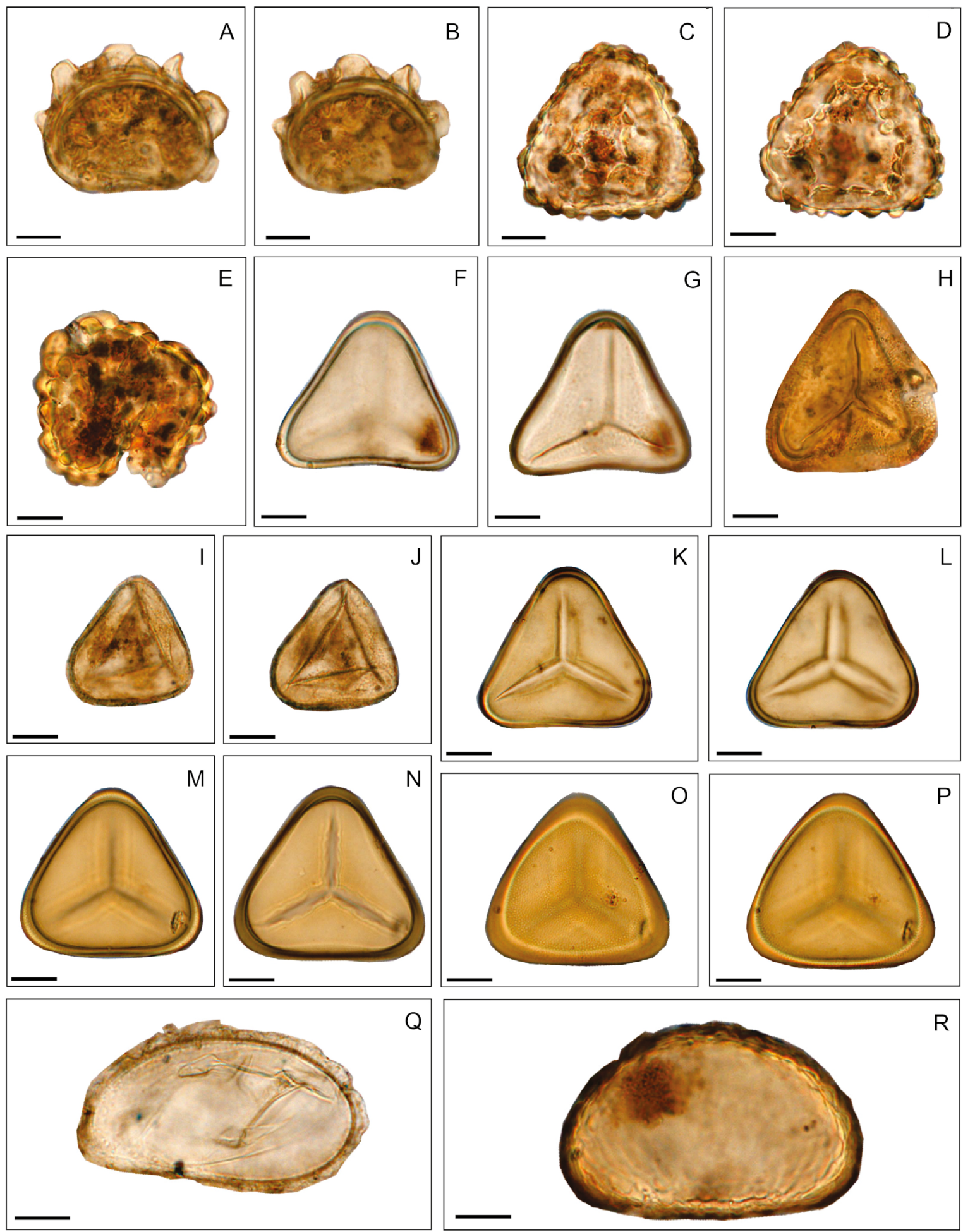

Figure 9. Observed spores at Mogi Guaçu Ecological Station (MGES) cores. A-B, Aspleniaceae; C-J, Cyathea sp.; K-P, Dicksoniaceae; Q, Thelypteris sp.; R, Polypodium sp. Scale bars $=10 \mu \mathrm{m}$.

not found in modern pollen rain. The isotopic values from $23.99 \%$ and $-24.39 \%$ o $\delta^{13} \mathrm{C}$ show the predominance of $\mathrm{C}_{3}$ plants (forest). The interval confirms the presence of a climate that allowed the forest development in the region (Pessenda et al., 1998). The charcoal fragments show that fires have occurred at MGES since Late Holocene.
- Stage II. Lp1/Lp2 Interval (Pedra Lake) 1,800 to $\sim 510$ BP. The Mauritia appears infrequently in the period, although other Arecaceae genera were present. The appearance of pollen grains of Arrabideae sp. (Bignoniaceae), Bombax sp. (Bombacaceae), Eugenia sp. (Myrtaceae), Tapirira sp. (Anacardiaceae) Curatella sp. (Dilleniaceae), 
Dalbergia sp. and Mimosa sp. (Fabaceae), and Gomphrena sp. (Amaranthaceae) shows a significant increase in Cerradão Forest elements in the stage, and the presence of Semideciduous-Riparian Forests, but not so spread.

- Stage III. Finally, the top of Lp1 (Fundão Lake), Lp3 (Pedra Lake), and Lc1 Intervals (Catingueiro Lake) ( $\sim 510$ BP to current days) show the current vegetation; the Semideciduous-Riparian Forest is better represented against a few pollen types of Cerradão Forest. Mauritia sp. and other Arecaceae genera occur significantly with the presence of flood areas promoting the expansion of SemideciduousRiparian Forest, and the contraction of Cerradão Forest. The isotopic analysis indicates that the forest is present, predominantly with $\mathrm{C}_{3}$ plants. The charcoal data confirm the occurrence of wildfires, as in previous stages, so that fire has always been usual at MGES throughout the Holocene.

\section{Comparison with other studies}

Based on paleoenvironmental analyzes made from the characterized stages, it was possible to compare data obtained at MGES with other nearby areas. In Stage I, about 2,730 years cal BP, the MGES experienced more humid climate than present days, with predominance of Semideciduous-Riparian Forest species represented by Arecaceae, Malpighiaceae, Myrtaceae and Euporbiaceae (Sebastiania sp.). Paleowildfires occurred throughout the interval. This inference is corroborated by the values of $\delta^{13} \mathrm{C}$ around -24 to -16 , which show the predominance of $\mathrm{C}_{3}$ plants (forest). The wetter phase can also be identified by palynological analysis (Celarino et al., 2013; Souza et al., 2013), and the predominance of Cerrado index plants, such as Didymopanax and Byrsonima, in the Jataí Ecological Station (JES) located about $50 \mathrm{~km}$ from MGES in Mogi Guaçu River, indicate that the vegetation was dense. The presence of humid climate was reported for Serra de Botucatu (Bissa \& Toledo, 2015) as well, where an increase of taxa from forested areas and Typha sp. occurred. A study in the Vereda do Chapadão dos Gerais (Buritizeiro, MG), between the ages 2,140 years (interpolated age) to 1,330 years cal BP, Cassino \& Meyer (2013) highlight that arboreal taxa from Cerrado and Forest were present in this period, concluding that the climatic oscillations that occurred in the area record the predominance of a more humid and hotter climate for that period. From $\sim 1,800$ to $\sim 510$ years cal BP (Stage II), it occurred the increase of Cerradão Forest taxa (i.e. Curatella sp.) and Mauritia appeared infrequently. Moreover, a change may have occurred in the floristic composition, previously composed by a vegetation mix of Semideciduous-Riparian and Cerradão forests. The isotopic analysis confirms the presence of a transition climate, demonstrated by the $\delta^{13} \mathrm{C}$ values characteristic of $\mathrm{C}_{3}$ (forest) plants. Charcoal fragments are still found, however, more frequent than in the previous interval. Storani \& Perez Filho (2015) report that approximately 1,900 years cal BP, a drier period prevailed in the area, followed by a humid period until current days. Gomes et al., (2017) conducted a research by using palynological and isotopic studies in Vereda Carrasco da Raposa, Serra do Cabral State Park, MG, Brazil. It was observed the occurrence of shrub and herbaceous elements, the increase of Cerrado trees, and the emergence of Mauritia flexuosa, suggesting that the climatic conditions in the Serra do Cabral between 3,550 $(25 \mathrm{~cm})$ and 1,650 years cal AP $(17 \mathrm{~cm})$ became more humid and hot compared to previous periods, with an average annual rainfall above $1,000 \mathrm{~mm}$, and the dry season lasting between five and six months. Those conditions have remained unchanged for the region so far. From $\sim 680 \mathrm{BP}$ to current days (Stage III), it is observed the increase of humidity, the return of Mauritia sp., and the decrease of Cerradão taxa.

\section{CONCLUSIONS}

The modern pollen rain predominantly represents the Semideciduous-Riparian Forest and some taxa of the current ecotone with the Cerrado. The record of pollen grains, isotopic and anthracological analyses in three abandoned meanders in the Mogi Guaçu River Basin, in São Paulo State, allowed the definition of three important periods for the area in the period from 2,730 years cal BP to the current days. Thus, we can make inferences about environmental evolution, vegetation reconstruction, and climate of the area. In the three lakes, the modern pollen rain shows that the Semideciduous-Riparian Forest taxa have prevailed over the Cerradão Forest elements, and a high percentage of spores is expected to humid periods, as it occurs currently. The results indicate that both forests remained present in all stages, varying their expansion depending on humidity. Thus, in wet periods, the Riparian Forest dominated with the expansion of endorheic zone influence. In less humid periods, it presented a reduction of endorheic zone, promoting the expansion of Cerradão Forest. The history of the Mogi Guaçu Ecological Station over the last 2,730 years cal BP has been an evidence to the sensitive balance of natural landscapes.

Finally, events of climatic pulsations have been identified in the study area in the last 2,730 years cal BP. Depositional processes were altered by erosive processes, due to climatic anomalies that altered and modified the morphology of river channel. Such scenarios reinforce the relevance of paleoenvironmental studies in areas of river deposition and abandoned meanders, despite being complex sedimentation environments.

\section{ACKNOWLEDGEMENTS}

The authors thank The Ecological Station of Mogi Guaçu and the Forestry Institute - SP for allowing the collect of samples and cores. We thank CAPES for providing a PhD grant, Brazilian National Council for Scientific and Technological Development (Researcher Grant No 303527/2017-0), and FAPESP for financial support according to process 2010/20379-6 "Quaternary paleoenvironmental analysis of Cerrado/Atlantic Forest ecotones in the municipality of Mogi Guaçu, SP". FAEPEX, through the agreement No. 519 292, request No. 0934/14 by Congress Grant. 


\section{REFERENCES}

Amaral, P.G.C.; Ledru, M.P.; Ricardi-Branco, F. \& Giannini, P.C. 2006. Late Holocene development of a mangrove ecosystem in southeastern Brazil (Itanhaém, state of São Paulo). Palaeogeography, Palaeoclimatology, Palaeoecology, 241:608620. doi: 10.1016/j.palaeo.2006.04.010

Aquino, C.; Barbosa, L.M.; Shirasuna, R.T. \& Barnuevo, S. 2013. Aspectos da regeneração natural e do estabelecimento de espécies arbóreas e arbustivas em área ciliar revegetada junto ao Rio Mogi-Guaçu, SP, Brasil. Hoehnea, 40:437-448. doi:10.1590/S2236-89062013000300004

Batista, E.A. \& Couto, H.T.Z. 1990. Influência de fatores químicos e físicos do solo sobre o desenvolvimento da vegetação de Cerrado na Reserva Biológica de Moji Guaçu, SP. Revista do Instituto Florestal, 2:69-86.

Bissa, W.M. \& Toledo, M.B. 2015. Late Quaternary vegetational changes in a marsh forest in Southeastern Brazil with comments on prehistoric human occupation. Radiocarbon, 57:737-753. doi:10.2458/azu_rc.57.18198

Bronk Ramsey, C. 2001. Development of the Radiocarbon calibration program. Radiocarbon, 43:355-363. doi:10.1017/ S0033822200038212

Byrnes, M.E. 1994. Field sampling methods for remedial investigations. Boca Raton, CRC Press Inc., 344 p.

Carreira, L.M.M. \& Barth, O.M. 2003. Atlas de pólen da vegetação de canga da Serra de Carajás, Pará, Brasil. Belém, Museu Paraense Emílio Goeldi, 112 p.

Carreira, L.M.M.; Lopes, J.R.C.; Silva, M.F. \& Nascimento, L.A.S. 1996. Catálogo de Pólen das Leguminosas da Amazônia Brasileira. Belém, Museu Paraense Emílio Goeldi, 137p.

Cassino R.F. \& Meyer, K.E.B. 2013. Reconstituição paleoambiental do Chapadão dos Gerais (Quaternário Tardio) a partir da análise palinológica da Vereda Laçador, Minas Gerais, Brasil. Revista Brasileira de Paleontologia, 16:127-146. doi:10.4072/ rbp.2013.1.10

Cassino, R.F.; Martinho, C.T. \& Caminha, S.A.F.S. 2015. Modern pollen spectra of the Cerrado vegetation in two national parks of Central Brazil, and implications for interpreting fossils pollen records. Review of Palaeobotany and Palynology, 223:71-86. doi:10.1016/j.revpalbo.2015.09.002

Celarino, A.L.S.; Souza, M.M.; Ladeira, F. \& Ricardi-Branco, F. 2013. Paleoenvironmental reconstruction of the Lower Mogi Guaçu River Basin (São Paulo State-Brazil), morphopedosedimentary records and fluvial processes. Catena, 111:80-97. doi:10.1016/j. catena.2013.07.002

CBH-Mogi. 1999. Diagóstico da Bacia Hidrográfica do Rio MogiGuaçu. "Relatório Zero". CBH-Mogi, CREUPI, 252 p.

Colinvaux, P.A.; De Oliveira, P.E. \& Moreno, J.E. 1999. Amazon pollen manual and atlas. London, CRC Press, $310 \mathrm{p}$.

Court, P. 1974. Nouvelles techniques de detection des flux et des retombées polliniques: étude de la sedimentation des pollens et des spores a la surface du sol. Pollen et Spores, 16:103-141.

Durigan, G. 1994. Florística, fitossociologia e produção de folhedo em matas ciliares da Região Oeste do Estado de São Paulo. Instituto de Biologia, Universidade Estadual de Campinas, Ph.D. thesis, 149 p.

Durigan, G.; Ratter, J.A.; Bridgewater, S.; Siqueira, M.F. \& Franco, G.A.D.C. 2003. Padrões fitogeográficos do cerrado paulista sob uma perspectiva regional. Hoenea, 30:39-51.
Eiten, G. 1963. Habitat flora of Fazenda Campininha, São Paulo, Brazil. In: M.G. Ferri (coord.) Simpósio sobre o Cerrado, Edgard Blucher e EDUSP, p. 157-202.

Faegri, K. \& Iversen, J. 1989. Textbook of pollen analysis. New York, John Wiley \& Sons, 328 p.

Gibbs, P.E. \& Leitão Filho, H.F. 1978. Floristic composition of an area of gallery forest near Mogi Guaçu, State of São Paulo, Brazil. Revista Brasileira de Botânica, 1:15-156.

Gibbs, P.E.; Leitão, H.F.F \& Shepherd, G.J. 1983. Floristic composition and community structure in an area of cerrado in SE Brazil. Flora, 173:433-449.

Gomes, B.Z.; Martins, F.R. \& Tamashiro, J.Y. 2004. Estrutura do cerradão e da transição entre cerradão e floresta paludícola num fragmento da International Paper do Brasil Ltda., em Brotas, SP. Revista Brasileira de Botânica, 27:249-262.

Gomes, M.O.S; Meyer, K.E.B. \& Pessenda, L.C.R. 2017. Reconstituição paleoambiental da Vereda Carrasco da Raposa, Parque Estadual da Serra do Cabral, MG, Brasil, por meio de estudos palinológico e isotópico. Pesquisas em Geociências, 44:41-62. doi:10.22456/1807-9806.79586

Graham, A. 2011. A natural history of the New World: the ecology and evolution on plants in the Americas. Chicago, The University of Chicago Press, $387 \mathrm{p}$.

Hogg, A.G.; Hua, Q.; Blackwell, P.G.; Niu, M.; Buck, C.E.; Guilderson, T.P.; Heaton, T.J.; Palmer, J.G.; Reimer, P.J.; Reimer, R.W.; Turney, C.S.M. \& Zimmerman, S.R.H. 2013. Shcal13 Southern Hemisphere calibration, 0-50,000 years cal BP. Radiocarbon, 55:1889-1903. doi:10.2458/azu_js_rc.55.16783

Lobo, I.; Mozeto, A. \& Aravena, R. 2001. Paleohydrological investigation of Infernão lake, Moji-Guaçu River watershed, São Paulo, Brazil. Journal of Paleolimnology, 26:119-129. doi:10.1023/A:1011145227967

Mantovani, W. \& Martins, F.R. 1988. Variações fenológicas das espécies do cerrado da Reserva Biológica de Moji Guaçu, Estado de São Paulo. Revista Brasileira de Botânica, 11:101-112.

Mantovani, W. \& Martins, F.R. 1993. Florística do cerrado na reserva biológica de Moji Guaçu, SP. Acta Botânica Brasileira, 7:33-60.

Mantovani, W.; Leitão, G.F. \& Martins, F.R. 1985. Chave baseada em caracteres vegetativos para identificação de espécies lenhosas do cerrado da Reserva Biológica de Moji Guaçu, Estado de São Paulo. Hoehnea, 12:35-56.

Mantovani, W.; Rossi, L.; Romaniuc Neto, S.; Ludewigs, I.Y.A.; Wanderley, M.G.L.; Melo, M.M.R.F. \& Toledo, C.B. 1989. Estudo fitossociológico de áreas de mata ciliar em Moji Guaçu, SP - Brasil. SIMPÓSIO SOBRE MATA CILIAR, 1989. Anais, São Paulo, vol. 1, p. 235-267.

Markgraf, V. \& D’Antoni, H.L. 1978. Pollen flora of Argentina. Tucson, University of Arizona Press, 208 p.

Oliveira-Filho, A.T.; Budke, J.C.; Jarenkow, J.A.; Eisenlohr, P.V. \& Neves, D.R.M. 2013. Delvind into variations in tree species composition and richness across South American subtropical Atlantic and Pampean forest. Journal of Plant Ecology, 2:1-23. doi:10.1093/jpe/ett058

Perrota, M.M. et al. 2005. Mapa Geológico do Estado de São Paulo, escala 1:750.000. São Paulo, CPRM.

Pessenda, L.C.R.; Valencia, E.P.E.; Aravena, R.; Telles, E.C.C. \& Boulet, R. 1998. Paleoclimate studies on Brazil using carbon isotopes in soils. In: J.C. Wasserman; E. Silva-Filho \& R. Villas-Boas (eds.) Environmental geochemistry in the tropics, Springer, p. 7-16. 
Pessenda, L.C.R.; Gouveia, S.E.M.; Freitas, H.A.; Ribeiro, A.S.; Aravena, R.; Bendassolli, J.A.; Ledru, M.P. \& Scheelybert, R. 2005. Isótopos do carbono e suas aplicações em estudos paleoambientais. In: C.R.G. Souza; K. Suguio; A.M.S. Oliveira \& P.E. De Oliveira (eds.). Quaternário do Brasil, Holos Editora, p. 75-93.

Ribeiro, J.F. \& Walter, B.M.T. 2008. As principais fitofisionomias do Bioma Cerrado. In: S.M. Sano; S.P. Almeida \& J.F. Ribeiro (eds.) Cerrado: ecologia eflora, Embrapa Cerrados, vol. 1, p. 153-212.

Ricardi-Branco, F.; Pereira, S.Y.; Souza, M.M.; Santiago, F.; Pereira, P.B.; Branco, F.; Ribeiro, V. \& Molina, K. 2015. Quaternary studies of Mogi-Guaçu River alluvial plain, SP, Brazil, focusing the relationships among subaquatic environment and leaf/palinomorphs assemblages. In: M. Ramkumar (ed.) Environmental Management of River Basin Ecosystems, Springer Earth System Sciences, p. 667-705.

Salgado-Labouriau, M.L. 1973. Contribuição à palinologia dos cerrados. Rio de Janeiro, Academia Brasileira de Ciências, 291 p.

Silva, C.I.; Ballesteros, P.L.O.; Palmero, M.A.; Bauermann, S.A.; Evaldit, A.C.P. \& Oliveira, P.E. 2010. Catálogo polínico Palinologia aplicada em estudos de conservação de abelhas do gênero Xylocopa no Triângulo Mineiro. Uberlândia, Editora da Universidade Federal de Uberlândia, 154 p.

Siqueira, M.F. \& Durigan, G. 2007. Modeling geographic distribution of "cerrado" woddy species in São Paulo State. Revista Brasileira de Botânica, 30:233-243. doi:10.1590/S010084042007000200008
Souza, M.M.; Ricardi-Branco F.; Jasper A. \& Pessenda, L.C.R. 2013. Evolução paleoambiental holocênica da porção nordeste do Estado de São Paulo, Brasil. Revista Brasileira de Paleontologia, 16:297-308. doi:10.4072/rbp.2013.2.10

Storani, D.L. \& Perez Filho, A. 2015. Novas informações sobre geocronologia em níveis de baixo terraço fluvial do rio Mogi Guaçu, SP, Brasil. Revista Brasileira de Geomorfologia, 16:191-199. doi:10.20502/rbg.v16i2.656

Whitlock, C. \& Larsen, C. 2001. Charcoal as a fire proxy. In: J.P. Smol; H.J.B. Birks \& W.M. Last (eds.) Tracking environmental change using lake sediments. Volume 3: Terrestrial, Algal, and Siliceous Indicators. Dordrecht, Kluwer Academic Publishers, $371 \mathrm{p}$.

Zancopé, M.H.C. \& Perez Filho, A. 2006. Considerações a respeito da distribuição das Planícies Fluviais do Rio Mogi Guaçu. Revista Brasileira de Geomorfologia, 7:65-71.

Zancopé, M.H.C.; Perez Filho, A. \& Carpi, Jr. 2009. Anomalias no perfil longitudinal e migração dos meandros do Rio Mogi Guaçu. Revista Brasileira de Geomorfologia, 10:31-42. doi:10.20502/ rbg.v10i1.115

Received in 05 August, 2020; accepted in 13 March, 2021. 
Appendix 1. List of comparation of types found in the modern pollen rain and cores Fundão, Pedra, and Catingueiro lakes.

\begin{tabular}{|c|c|c|c|c|c|c|c|c|c|c|c|}
\hline \multirow{3}{*}{$\begin{array}{l}\text { Place } \\
\text { Taxa }\end{array}$} & \multicolumn{3}{|c|}{ Current pollen rain } & \multicolumn{5}{|c|}{ Fossil assemblages } & \multirow{3}{*}{$\begin{array}{c}\text { Cerradão } \\
\text { Forest }\end{array}$} & \multirow{3}{*}{$\begin{array}{c}\text { Riparian } \\
\text { Forest }\end{array}$} & \multirow{3}{*}{ Ecotone } \\
\hline & \multirow{2}{*}{ Fundão } & \multirow{2}{*}{ Pedra } & \multirow{2}{*}{ Catingueiro } & \multirow{2}{*}{$\begin{array}{c}\text { Fundão } \\
\text { Lf1 }\end{array}$} & \multicolumn{3}{|c|}{ Pedra } & \multirow{2}{*}{$\begin{array}{c}\text { Catingueiro } \\
\mathrm{Lc}\end{array}$} & & & \\
\hline & & & & & Lp1 & Lp2 & Lp3 & & & & \\
\hline \multicolumn{12}{|c|}{ Arboreal Pollen (AP) } \\
\hline Anacardiaceae & & & & $\mathrm{X}$ & & & $\mathrm{X}$ & $\mathrm{X}$ & & $\mathrm{X}$ & \\
\hline Astronium sp. & & & & & & & & $\mathrm{X}$ & $\mathrm{X}$ & & \\
\hline Tapirira sp. & & & & & & & & & $\mathrm{X}$ & & \\
\hline \multicolumn{12}{|l|}{ Annonaceae } \\
\hline Annona sp. & & & & & & & $\mathrm{X}$ & & $\mathrm{X}$ & & \\
\hline Diclinanona sp. & & & & & & & & & & & $\mathrm{X}$ \\
\hline Aquifoliaceae & & & & & & & $\mathrm{X}$ & & & & \\
\hline Ilex $\mathrm{sp}$. & & & & $\mathrm{X}$ & & $\mathrm{X}$ & $\mathrm{X}$ & $\mathrm{X}$ & $\mathrm{X}$ & & \\
\hline Apocynaceae & $\mathrm{X}$ & & $\mathrm{X}$ & & & $\mathrm{X}$ & & $\mathrm{X}$ & & $\mathrm{X}$ & \\
\hline Aspidosperma sp. & & & & & & & & $\mathrm{X}$ & $\mathrm{X}$ & & \\
\hline Secondatia sp. & & & & & & $\mathrm{X}$ & & & & $\mathrm{X}$ & \\
\hline Araliaceae & $\mathrm{X}$ & $\mathrm{X}$ & $\mathrm{X}$ & $\mathrm{X}$ & & $\mathrm{X}$ & $\mathrm{X}$ & & & & $\mathrm{X}$ \\
\hline Arecaceae & $\mathrm{X}$ & $\mathrm{X}$ & $\mathrm{X}$ & $\mathrm{X}$ & $\mathrm{X}$ & $\mathrm{X}$ & $\mathrm{X}$ & $\mathrm{X}$ & & $\mathrm{X}$ & \\
\hline Mauritia sp. & & & $\mathrm{X}$ & & & $\mathrm{X}$ & & $\mathrm{X}$ & & $\mathrm{X}$ & \\
\hline Bignonaceae & & & & $\mathrm{X}$ & & & & & & $\mathrm{X}$ & \\
\hline \multicolumn{12}{|l|}{ Dillenaceae } \\
\hline Curatella sp. & & & & & & $\mathrm{X}$ & & & $\mathrm{X}$ & & \\
\hline Tetracera sp. & & & & & & $\mathrm{X}$ & & & $\mathrm{X}$ & & \\
\hline Euphorbiaceae & & & & $\mathrm{X}$ & $\mathrm{X}$ & $\mathrm{X}$ & $\mathrm{X}$ & & & & $\mathrm{X}$ \\
\hline Euphorbia sp. & $\mathrm{X}$ & $\mathrm{X}$ & $\mathrm{X}$ & & & & & & & & \\
\hline Sebastiana sp. & $\mathrm{X}$ & & $\mathrm{X}$ & $\mathrm{X}$ & & $\mathrm{X}$ & $\mathrm{X}$ & $\mathrm{X}$ & $\mathrm{X}$ & & \\
\hline \multicolumn{12}{|l|}{ Fabaceae } \\
\hline Acosmium sp. & & & & & $\mathrm{X}$ & & & & & $\mathrm{X}$ & \\
\hline Anadenanthera sp. & & & & $\mathrm{X}$ & & $\mathrm{X}$ & & & & $\mathrm{X}$ & \\
\hline Copaifera sp. & & & & & $\mathrm{X}$ & $\mathrm{X}$ & $\mathrm{X}$ & $\mathrm{X}$ & & $\mathrm{X}$ & \\
\hline Dalbergia sp. & & & & $\mathrm{X}$ & $\mathrm{X}$ & $\mathrm{X}$ & & $\mathrm{X}$ & $\mathrm{X}$ & & \\
\hline Dinizia sp. & & & & & & $\mathrm{X}$ & & & & & $\mathrm{X}$ \\
\hline Diplotropis sp. & & & & $\mathrm{X}$ & & & & & $\mathrm{X}$ & & \\
\hline Pterocarpus sp. & & & & & $\mathrm{X}$ & & & & $\mathrm{X}$ & & \\
\hline Malvacea/Bombacaceae & & & & & & $\mathrm{X}$ & & $\mathrm{X}$ & $\mathrm{X}$ & & $\mathrm{X}$ \\
\hline Bombax sp. & & & & $\mathrm{X}$ & & & & & $\mathrm{X}$ & & \\
\hline Malpighiaceae & $\mathrm{X}$ & $\mathrm{X}$ & & $\mathrm{X}$ & $\mathrm{X}$ & $\mathrm{X}$ & $\mathrm{X}$ & & & & $\mathrm{X}$ \\
\hline Peixotoa sp. & & & & $\mathrm{X}$ & & $\mathrm{X}$ & & & & & $\mathrm{X}$ \\
\hline Melastomataceae & $\mathrm{X}$ & & $\mathrm{X}$ & & $\mathrm{X}$ & $\mathrm{X}$ & $\mathrm{X}$ & $\mathrm{X}$ & & $\mathrm{X}$ & \\
\hline
\end{tabular}




\begin{tabular}{|c|c|c|c|c|c|c|c|c|c|c|c|}
\hline \multirow{3}{*}{$\begin{array}{l}\text { Place } \\
\text { Taxa }\end{array}$} & \multicolumn{3}{|c|}{ Current pollen rain } & \multicolumn{5}{|c|}{ Fossil assemblages } & \multirow{3}{*}{$\begin{array}{l}\text { Cerradão } \\
\text { Forest }\end{array}$} & \multirow{3}{*}{$\begin{array}{c}\text { Riparian } \\
\text { Forest }\end{array}$} & \multirow{3}{*}{ Ecotone } \\
\hline & \multirow{2}{*}{ Fundão } & \multirow{2}{*}{ Pedra } & \multirow{2}{*}{ Catingueiro } & \multirow{2}{*}{$\begin{array}{c}\text { Fundão } \\
\text { Lf1 }\end{array}$} & \multicolumn{3}{|c|}{ Pedra } & \multirow{2}{*}{$\begin{array}{c}\text { Catingueiro } \\
\text { Lc }\end{array}$} & & & \\
\hline & & & & & Lp1 & Lp2 & Lp3 & & & & \\
\hline Mimosaceae & $\mathrm{X}$ & $\mathrm{X}$ & $\mathrm{X}$ & & & & & & & & \\
\hline Mimosa sp. & & & & $\mathrm{X}$ & $\mathrm{X}$ & $\mathrm{X}$ & $\mathrm{X}$ & $\mathrm{X}$ & $\mathrm{X}$ & & \\
\hline \multicolumn{12}{|l|}{ Myrcinaceae } \\
\hline Myrcine sp. & & & & & & $\mathrm{X}$ & $\mathrm{X}$ & & & & $\mathrm{X}$ \\
\hline Myrtaceae & $\mathrm{X}$ & $\mathrm{X}$ & $\mathrm{X}$ & $\mathrm{X}$ & & $\mathrm{X}$ & $\mathrm{X}$ & $\mathrm{X}$ & & $\mathrm{X}$ & \\
\hline Myrcia sp. & & & & $\mathrm{X}$ & & & & & & & \\
\hline Eugenia sp. & & & & $\mathrm{X}$ & & $\mathrm{X}$ & & & $\mathrm{X}$ & & \\
\hline \multicolumn{12}{|l|}{ Pinaceae } \\
\hline Pinus sp. & $\mathrm{X}$ & $\mathrm{X}$ & $\mathrm{X}$ & $\mathrm{X}$ & & & & & & & \\
\hline \multicolumn{12}{|l|}{ Phyllanthaceae } \\
\hline Phyllanthus sp. & & & & & & $\mathrm{X}$ & & & & & $\mathrm{X}$ \\
\hline Podocarpaceae & & & & & & & & & $\mathrm{X}$ & & \\
\hline Podocarpus sp. & & & & $\mathrm{X}$ & & $\mathrm{X}$ & & & & & \\
\hline \multicolumn{12}{|l|}{ Primulaceae } \\
\hline Cybianthus sp. & & & & & & $\mathrm{X}$ & & & & $\mathrm{X}$ & \\
\hline \multicolumn{12}{|l|}{ Salicaceae } \\
\hline Banara sp. & & & & & & $\mathrm{X}$ & & & & $\mathrm{X}$ & \\
\hline Sapindaceae & & & & $\mathrm{X}$ & & $\mathrm{X}$ & & & & $\mathrm{X}$ & \\
\hline Cupania sp. & & & & & & $\mathrm{X}$ & & & & $\mathrm{X}$ & \\
\hline Paullinia sp. & & & & & & $\mathrm{X}$ & & & & & $\mathrm{X}$ \\
\hline Sapotaceae & & $\mathrm{X}$ & & & & & & & & & \\
\hline \multicolumn{12}{|c|}{ Non Arboreal Pollen (NAP) } \\
\hline Amaranthaceae & $\mathrm{X}$ & $\mathrm{X}$ & $\mathrm{X}$ & & & & & & $\mathrm{X}$ & $\mathrm{X}$ & $\mathrm{X}$ \\
\hline Alternanthera sp. & & & & & $\mathrm{X}$ & $\mathrm{X}$ & & & & & $\mathrm{X}$ \\
\hline Amaranthus sp. & & & & & $\mathrm{X}$ & $\mathrm{X}$ & $\mathrm{X}$ & & $\mathrm{X}$ & & \\
\hline Chenopodium sp. & & & & & & $\mathrm{X}$ & & & & $\mathrm{X}$ & $\mathrm{X}$ \\
\hline Gomphrena sp. & & & & & $\mathrm{X}$ & $\mathrm{X}$ & $\mathrm{X}$ & & $\mathrm{X}$ & & \\
\hline \multicolumn{12}{|l|}{ Apiaceae } \\
\hline Eryngium sp. & & & & & & $\mathrm{X}$ & $\mathrm{X}$ & & & $\mathrm{X}$ & \\
\hline Asteraceae & $\mathrm{X}$ & $\mathrm{X}$ & $\mathrm{X}$ & $\mathrm{X}$ & $\mathrm{X}$ & $\mathrm{X}$ & $\mathrm{X}$ & $\mathrm{X}$ & & & $\mathrm{X}$ \\
\hline Bromeliaceae & & & & & & $\mathrm{X}$ & $\mathrm{X}$ & & & & $\mathrm{X}$ \\
\hline Ericaceae & & & & & & & & $X$ & & & \\
\hline \multicolumn{12}{|l|}{ Convolvulaceae } \\
\hline Ipomea sp. & & & & & & $\mathrm{X}$ & & & & $\mathrm{X}$ & \\
\hline Lamiaceae & $\mathrm{X}$ & & & & & $\mathrm{X}$ & & & & & $\mathrm{X}$ \\
\hline
\end{tabular}




\begin{tabular}{|c|c|c|c|c|c|c|c|c|c|c|c|}
\hline \multirow{3}{*}{$\begin{array}{l}\text { Place } \\
\text { Taxa }\end{array}$} & \multicolumn{3}{|c|}{ Current pollen rain } & \multicolumn{5}{|c|}{ Fossil assemblages } & \multirow{3}{*}{$\begin{array}{l}\text { Cerradão } \\
\text { Forest }\end{array}$} & \multirow{3}{*}{$\begin{array}{l}\text { Riparian } \\
\text { Forest }\end{array}$} & \multirow{3}{*}{ Ecotone } \\
\hline & \multirow{2}{*}{ Fundão } & \multirow{2}{*}{ Pedra } & \multirow{2}{*}{ Catingueiro } & \multirow{2}{*}{$\begin{array}{c}\text { Fundão } \\
\text { Lf1 }\end{array}$} & \multicolumn{3}{|c|}{ Pedra } & \multirow{2}{*}{$\begin{array}{c}\text { Catingueiro } \\
\text { Lc } \\
\end{array}$} & & & \\
\hline & & & & & Lp1 & Lp2 & Lp3 & & & & \\
\hline \multicolumn{12}{|l|}{ Fabaceae } \\
\hline Galactia sp. & & & & & & $\mathrm{X}$ & & & $\mathrm{X}$ & & \\
\hline \multicolumn{12}{|l|}{ Lythraceae } \\
\hline Cuphea sp. & & & & & & $\mathrm{X}$ & $\mathrm{X}$ & & & & $\mathrm{X}$ \\
\hline Malvaceae & $\mathrm{X}$ & & & & & $\mathrm{X}$ & & & & & $\mathrm{X}$ \\
\hline Poaceae & $\mathrm{X}$ & $\mathrm{X}$ & $\mathrm{X}$ & $\mathrm{X}$ & $\mathrm{X}$ & $\mathrm{X}$ & $\mathrm{X}$ & $\mathrm{X}$ & & & $\mathrm{X}$ \\
\hline \multicolumn{12}{|l|}{ Polygalaceae } \\
\hline Polygala sp. & & & & & & $X$ & & $X$ & & & $X$ \\
\hline \multicolumn{12}{|l|}{ Polygonaceae } \\
\hline Polygonum sp. & & & & & & & $\mathrm{X}$ & & & & \\
\hline Rubiaceae & & $\mathrm{X}$ & $\mathrm{X}$ & $\mathrm{X}$ & & & $\mathrm{X}$ & & & & $\mathrm{X}$ \\
\hline Borreria sp. & & & & & $\mathrm{X}$ & $\mathrm{X}$ & & & $\mathrm{X}$ & & \\
\hline \multicolumn{12}{|l|}{ Solanaceae } \\
\hline Solanum sp. & & & & & & $\mathrm{X}$ & & & $\mathrm{X}$ & & \\
\hline \multicolumn{12}{|c|}{ Aquatics } \\
\hline Cyperaceae & $\mathrm{X}$ & $\mathrm{X}$ & $\mathrm{X}$ & $\mathrm{X}$ & $\mathrm{X}$ & $\mathrm{X}$ & $\mathrm{X}$ & $\mathrm{X}$ & & & \\
\hline \multicolumn{12}{|c|}{ Spores } \\
\hline Aspleniaceae & & & & & & & & & & $\mathrm{X}$ & \\
\hline Cyatheaceae & $\mathrm{X}$ & $\mathrm{X}$ & $\mathrm{X}$ & $\mathrm{X}$ & $\mathrm{X}$ & & & $\mathrm{X}$ & & $\mathrm{X}$ & \\
\hline Alsophila sp. & & & & & & $\mathrm{X}$ & & & & $\mathrm{X}$ & \\
\hline Cyathea sp. & & & & & $\mathrm{X}$ & $\mathrm{X}$ & $\mathrm{X}$ & & & $\mathrm{X}$ & \\
\hline Dicksoniaceae & $\mathrm{X}$ & & & $\mathrm{X}$ & $\mathrm{X}$ & $\mathrm{X}$ & & $\mathrm{X}$ & & $\mathrm{X}$ & \\
\hline \multicolumn{12}{|l|}{ Lycopodiaceae } \\
\hline Lycopodium sp. & $\mathrm{X}$ & & & & & $\mathrm{X}$ & & & & $\mathrm{X}$ & \\
\hline \multicolumn{12}{|l|}{ Osmundaceae } \\
\hline Osmunda sp. & & & & & & $\mathrm{X}$ & & & & $\mathrm{X}$ & \\
\hline \multicolumn{12}{|l|}{ Polypodiaceae } \\
\hline Polypodium sp. & $\mathrm{X}$ & $\mathrm{X}$ & $\mathrm{X}$ & & $\mathrm{X}$ & $\mathrm{X}$ & & $\mathrm{X}$ & & $\mathrm{X}$ & \\
\hline Thelypteridaceae & $\mathrm{X}$ & & & & & $\mathrm{X}$ & $\mathrm{X}$ & & & & \\
\hline Thelypteris sp. & & & & & & & & & & $\mathrm{X}$ & \\
\hline \multicolumn{12}{|l|}{ Schizaeaceae } \\
\hline Schizaea sp. & & & & & & & $\mathrm{X}$ & & & $\mathrm{X}$ & \\
\hline \multicolumn{12}{|l|}{ Selaginellaceae } \\
\hline Selaginella sp. & & & & & & $\mathrm{X}$ & & & & $\mathrm{X}$ & \\
\hline Indeterminates & $\mathrm{X}$ & $\mathrm{X}$ & $\mathrm{X}$ & & $\mathrm{X}$ & $\mathrm{X}$ & $\mathrm{X}$ & $\mathrm{X}$ & & & \\
\hline
\end{tabular}

